\title{
The schooling response to a sustained increase in low-skill wages: evidence from Spain 1989-2009
}

\author{
Aitor Lacuesta $^{1}$ (D) Sergio Puente ${ }^{1} \cdot$ Ernesto Villanueva $^{1}$ \\ Received: 11 September 2019 / Accepted: 17 June 2020 / Published online: 25 July 2020 \\ (c) The Author(s) 2020
}

\begin{abstract}
The response of human capital accumulation to changes in the anticipated returns to schooling determines the type of skills supplied to the labor market, the productivity of future cohorts, and the evolution of inequality. Unlike the USA, the UK or Germany, Spain has experienced between 1995 and 2008 a drop in the returns to medium and tertiary education and, with a lag, a drop in schooling attainment of recent cohorts, providing the setup to estimate the response of different forms of human capital acquisition to relative increases in low-skill wages. We measure the expected returns to schooling using skill-specific wages bargained in collective agreements at the province-industry level. We argue that those wages are easily observable by youths and relatively insensitive to shifts in the supply of workers. Our preferred estimates suggest that a $10 \%$ increase in the ratio of wages of unskilled workers to the wages of mid-skill workers increases the fraction of males completing at most compulsory schooling by between 2 and 6.5 percentage points. The response is driven by males from less educated parents and comes at the expense of students from the academic high school track-rather than the vocational training track.
\end{abstract}

Keywords Collective contracts · Human capital · Investment in skills

JEL Classification J52 (collective bargaining) · J24 (human capital)

\footnotetext{
We thank seminar audiences at CEPS-INSTEAD, the 2010 EALE meetings in London, the 2010

Simposio of Analisis Economico at Madrid, the 2011 SOLE Meetings at Vancouver, the August 2011

Meetings of the Econometric Society at Oslo and the 2011 IZA-ESSLE workshop at

Buch-am-Ammersee. For their helpful comments, we would like to thank Ana Rute Cardoso, Giacomo de Giorgi, Juan Francisco Jimeno, Laura Hospido, Francis Kramarz, Josep Pijoan and Núria

Rodriguez-Planas. Mario Izquierdo provided very useful help with the Registry of Collective Agreements Database. All views and opinions are our own.
}

\footnotetext{
$凶$ Aitor Lacuesta

aitor.lacuesta@bde.es

1 Banco de Espana, Madrid, Spain
} 


\section{Introduction}

The response of human capital to changes in anticipated returns to schooling determines the productivity of future cohorts and the evolution of inequality. Unlike other advanced economies, including the USA, the UK or Germany, Spain experienced between the mid-90s and the Great Financial Recession a drop both in the returns to medium and tertiary education, following the housing boom (see Pijoan-Mas and Sanchez-Marcos 2010; Lacuesta and Izquierdo 2012; Bonhomme and Hospido 2017). This paper estimates how educational attainment responds to increases in low-skill wages relative to high-skill.

The basic model of human capital acquisition stresses the role of the expected return to skill acquisition as a key determinant of the decision to enroll in formal education-see Becker (1962). In the absence of credit constraints, the opportunity cost of attending school relative to expected returns of acquiring formal skills determines the supply of human capital in an economy. On the empirical side, there is evidence that young adults' enrollment probabilities decrease with the wages of unskilled workers - Sanders et al. (2005), Neumark and Wascher (1995) - the unemployment rate-Clark (2011) for the UK, Dellas and Sakellaris (2003) for the USA, Petrongolo and San Segundo (2002) for Spain —or proxies for the demand in industries intensive in unskilled labor (Black et al. 2005; Atkin 2016; Charles et al. 2018).

While school enrollment is a very important outcome, it provides little information about the type of skills that are finally acquired in formal education. Firstly, early school leaving decisions may be compensated later on by other forms of human capital acquisition, such as GEDs in the USA. Secondly, being enrolled in school for some time does not guarantee the acquisition of the final title pursued. Despite this fact, less is known regarding the relationship between expected returns and educational attainment. We concentrate on that particular margin, similarly to Abramitzky and Lavy (2014) and Aparicio (2016). In particular, Abramitzky and Lavy (2014) examine changes in high school completion in kibbutzim where full income pooling among all members was substituted by a distribution of income that let individuals obtaining their full earnings. More closely related to our object of study, Aparicio (2016) analyzes the relationship of the difference in the completion of non-compulsory courses between men and women by regions in Spain and the difference of their corresponding ratios of skill and unskilled wages. She instrumented the skill premium with the share of the construction activity in each region exploiting the fact that the housing boom shall benefit males in a differential way.

To our knowledge, we provide one of the first estimates of the response of the supply of academic or professional skills to changes in (potentially) observable measures of the wage structure. Using a different technique López-Mayán (2010) estimates a structural model of grade progression in Spain for the 1985 cohort, finding that students of vocational training are most sensitive to relative changes in the return to vocational training. Her estimation uses actual wages. This measure of economic opportunities might be potentially contaminated by changes in the composition of the workforce. This point is going to be important in our paper as it will be clearer below. This distinction between the academic and the vocational track is relevant, because the type of skills obtained are very different, even for the same number of years studied. We 
document below that about $80 \%$ of workers with a college degree work in occupations with abstract tasks, such as managers, professionals or technicians. Comparatively, workers with vocational training degree concentrate in occupations that involve routine tasks, like assemblers, machine operators and craftsmen. Those patterns are consistent with the curricula of those studies. Recent evidence for a variety of countries has found a decline in the share of middle wage occupations (Autor et al. 2003; Goos et al. 2009; Anghel et al. 2014) and a drop in their relative wages, typically attributed to a decrease in the demand for occupations performing routine job contents and which can be easily mechanized. On the other hand, it has also been documented that occupations which perform jobs that are more difficult to be substituted by technology such as abstract qualified occupations or unqualified jobs which require interpersonal skills are rising in relative employment terms. As a consequence of this trend, losing university degree holders might decrease the capacity of an economy to cope with a growing demand of high-skill tasks. The tracked nature of the Spanish education system permits an examination of how responsive is the supply of the different set of abilities to increases in unskilled wages.

As already stated, and differently to all similar papers above, we treat the simultaneity between the quantities of unskilled workers entering the labor market and the relative changes in unskilled wages, by measuring the wage structure perceived by youths at the age of 17 using skill-specific wages determined in collective agreements at the province-industry level, distinguishing between unskilled, mid-skill and college wages. Agreed wages are better suited than actual wages in this setting because of three reasons. First, there is substantial concentration in the wages of the youth around collectively bargained wages for unskilled workers making them very "visible" for young adults who consider joining the labor. Second, the evolution of average agreed wages at the sector and province level are free of changes in the composition of workers as opposed to actual wages, something important in a context of massive creation of jobs. Finally, we argue that bargained wages are insensitive to changes in the supply of young workers due to the fact that unions primarily represent the interests of existing workers. Hence, the evolution of bargained wages might reflect changes in demand instead of changes in supply of youth workers. In order to test this last hypothesis, we show that the variation in wages set in collective agreements does not reflect the relative bargaining power of unskilled youth in the province-measured by the age-specific one-year lagged unemployment rate.

We document the following set of results. A $10 \%$ increase in the relative wages of unskilled workers, holding the returns to college constant, leads cohorts that turn 17 to be between 2 and 6 percentage points more likely to complete compulsory education only. The result depends on whether we adjust for unemployment differences across skill levels. The increase in the share of male youths with basic schooling comes at the expense of the share of male youth with academic high school track and is most pronounced among males whose mother have a lower level of schooling. We find weaker schooling response to the relative increase of unskilled wages among females, a finding that could be due to wage increases below those observed in construction in the industries where unskilled females work. Our results imply that the housing boom decreased the population educational attainment in Spain because of the abundance of low skill job opportunities and that it is expected that with its bust, educational 
attainment will recover. Our findings are in line with those that document how local booms affect enrollment, suggesting that youths react to the number of low-skilled jobs available [Black et al. (2005) for Appalachia, Atkin (2016), for Mexico, Aparicio (2016) for Spain, for the USA]. However, those studies cannot disentangle whether human capital investments respond to the number of jobs or to changes in the wage structure. In contrast, we study the human capital response to variations in observable measures of the wage structure that are orthogonal to the availability of jobs. Our results lend support to the notion that youths respond to wage changes.

In other contexts, it has been shown that wealth effects could act as a potential channel by which university enrollment might increase following a housing boom. In particular, Lovenheim (2011) documents an increase in US college enrollment derived from a wealth effect of low resource families - also coming from a housing boom. Easier access to finance may represent a lower bound of the total effect on schooling of the US housing boom if construction affects the educational decisions at other stages - see Charles et al. (2018) for estimates of the impact of housing boom on the employment of non-college workers. In Spain, it is not surprising that low-skilled wage opportunities dominate wealth effects because the cost of college enrollment in the sampling period was certainly small, and almost no one asked for a loan to pay university. ${ }^{1}$

Section 2 provides some background on schooling and wages in Spain. Section 3 discusses the wage measures we use. Section 4 describes the data and the methods. Section 5 shows the results regarding the effects of wages on enrollment and educational attainment. Section 6 provides some discussion about the results and implications. Finally, Sect. 7 concludes.

\section{Trends in wages and schooling in Spain}

This section provides the basic facts about educational attainment and the wage structure that each cohort could potentially have observed at the age of 17.

\subsection{The educational system and trends in schooling attainment}

Spain features a dual track educational system. Once a young adult finishes compulsory education, he or she may enter the academic track that gives access to college. The second route is vocational training (VT hereafter, Formación Profesional in Spanish), a professionally oriented track that involves training in firms and provides occupationspecific skills. Compared to students of the academic track (AT hereafter), VT students are more likely to work as machine operators, assemblers but less likely to be managers. In addition, according to the classification of Autor et al. (2003), they are also relatively more likely to perform routine tasks. The cohorts we examine were born between 1969 and 1984 and for them compulsory schooling ended at age 14 (see Footnote 2). After

\footnotetext{
1 According to the 2002 Encuesta Financiera de las Familias (Spanish Survey of Household Finance) 2\% of families with an outstanding loan for purposes other than the purchase of real estate had incurred a loan to finance schooling expenses.
} 
that age one could opt for leaving the system altogether, or for entering either the academic or the vocational training tracks.

The AT consisted of three grades, with common curricula during the first two years and partial choice of subjects during the last one. An additional grade plus passing a national-level exam ensured the access to college. The VT track consisted of three levels (or "modules"). The first two were assimilated to secondary schooling, and each of them consists of two academic year courses. The third one is assimilated to tertiary education by the definitions of Eurostat and the OECD. ${ }^{2}$

For the purpose of documentation of trends, we distinguish four levels: (1) Less than upper secondary; (2) Upper secondary school: This group includes all young adults who completed at least high school (in the AT); (3) (Any form of) Vocational training and (4) Tertiary education: any form of college.

Figure 1a shows the evolution of the percentage of males and females Spanish young adults born between 1966 and 1994, measured as of age 25 in the Spanish Labor Force Survey (EPA, by its Spanish initials). The EPA is the equivalent to the US Current Population Survey, described in Sect. 4. Figure 1a documents a rapid increase in the educational attainment of the cohorts born in the early seventies, followed by a process of stagnation among those born in the late seventies and eighties. Around $53 \%$ of male and $50 \%$ of female young adults born in 1966 had-at most - completed primary school at age 25 . That fraction dropped to $38 \%$ among the cohort of males born in 1976 and to $28 \%$ among the same cohort of females. ${ }^{3}$ The percentage of native males (females) completing compulsory schooling at most remained approximately constant among the cohorts born between 1978 and 1987, and the generation born in 1988 resumed the process of educational upgrading (see Fig. 1). Figure 1b documents the evolution of the percentages for the rest of degrees distinguishing between the academic track (upper secondary and university) and vocational training. The fraction of males born in 1976 with upper secondary school, college and vocational training at age 25 was, respectively 2, 6 and 7 percentage points higher than those of the 1966 cohort. Among females, the increase in educational attainment of females born in 1976 relative to those born in 1967 is most visible among college graduates: the fraction having completed college at 25 was 13 pp higher, while high school completion and vocational training increased by $4 \mathrm{pp}$ and $6 \mathrm{pp}$, respectively.

As mentioned above, schooling attainment basically stagnated among cohorts born in the late seventies and eighties. The percentage of males born in 1988 who had

\footnotetext{
2 A new Educational Act passed in 1990 but introduced in 1993 (LOGSE law 14/1990) extended compulsory education until age 16. The law specified that those who were attending 3rd and 4th degree of primary education in 1993 were to initiate 3rd and fourth degree of the "new" primary education. In principle, and according to such legislation, the first birth cohort completely affected by the new legislation would then be the one born in 1984. Some schools changed the system prior to 1993. Even in the case of change in 1993, some youths born before could have been affected by the reform if they repeated some grade.

Secondly, the reform maintained the first two grades of the academic and the vocational tracks in the former system as "compulsory" secondary education. Access to tertiary education or the composition of the last two grades of the vocational training remained unchanged. As we lack information about the share of students whose school anticipated the law change, we create a taxonomy of grades that is consistent over time, and discuss if legislative changes are likely to affect our measures of schooling attainment.

3 The sharpest improvement of female educational attainment during recent years in Spain relative to males is documented in Guner et al. (2014).
} 
$\mathbf{A}$
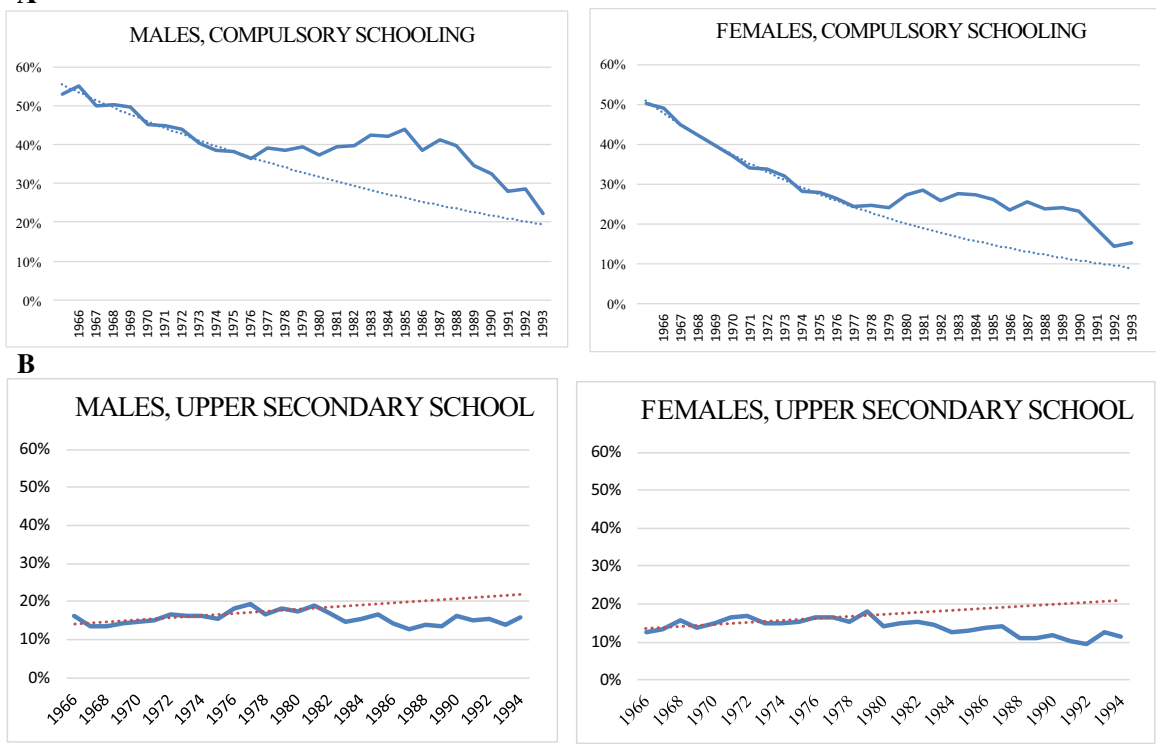

FEMALES, UPPER SECONDARY SCHOOL
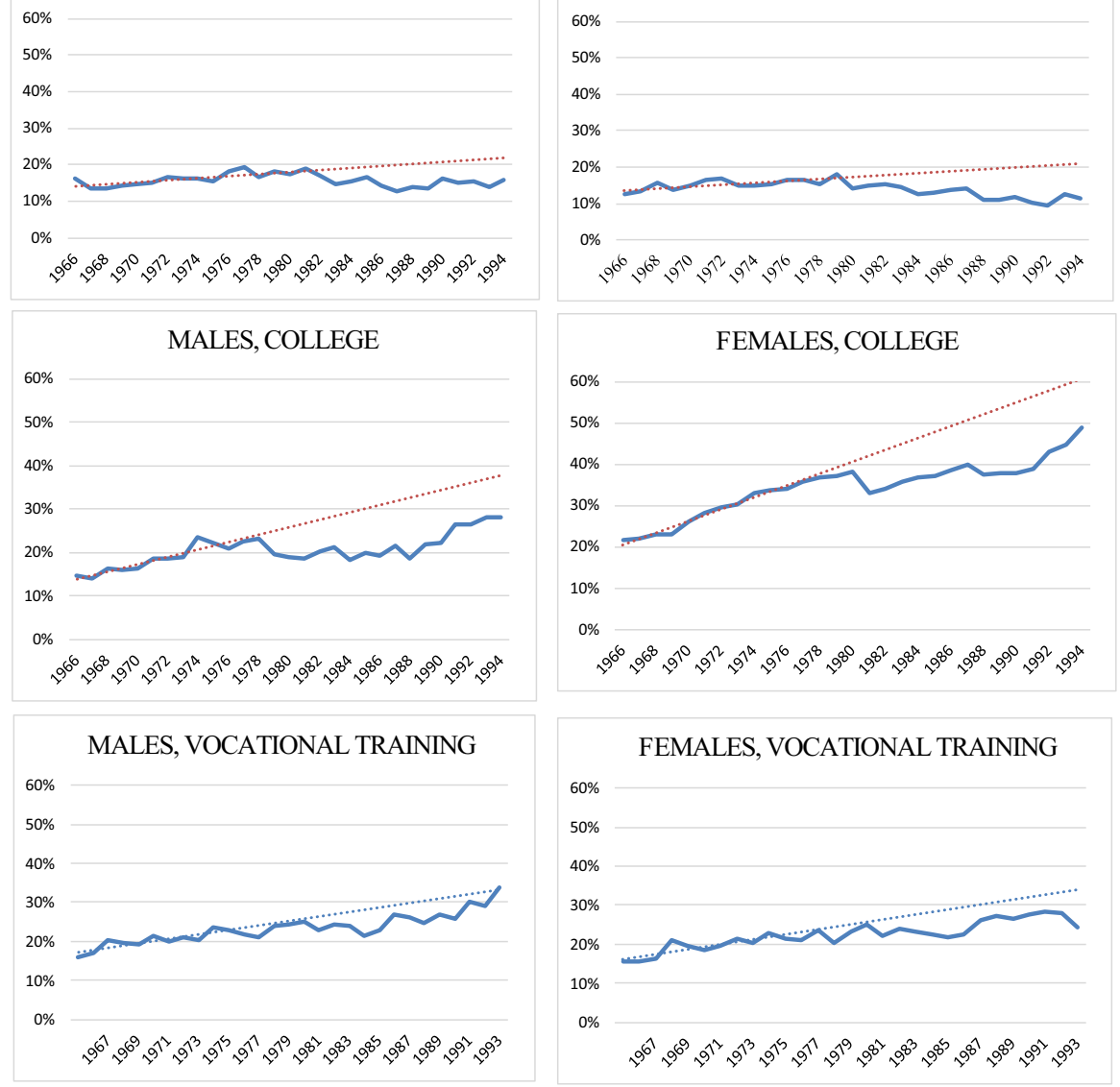

Fig. 1 Educational attainment at age 25 by year of birth, $\%$ of Spanish natives with compulsory education. a The straight line represents the percentage of people of different birth cohorts that did not achieve high school between 1966 and 1993. The dotted line shows a lineal trend of that percentage extrapolating from 1966 and 1976. In the regressions, we use the cohorts born between 1969 and 1984. b The straight line represents the percentage of people of different birth cohorts that achieved high school, college and a vocational degree between 1966 and 1993. The dotted line shows a lineal trend of those percentages extrapolating from 1966 and 1976. In the regressions, we use the cohorts born between 1969 and 1984. Source: EPA (Spanish Employment Survey), years 1992-2018 
completed upper secondary school (college) by age 25 was 4 pp (2pp) lower than that among individuals born in 1976. The fraction of males born in 1988 who had completed vocational training at the age of 25 was 3 pp higher than that observed for the 1976 cohort. Among females born in 1988, the percentage who had completed high school by age 25 was 6 pp lower than that observed among females born in 1977, a fall that was compensated by a $3 \mathrm{pp}$ increase in college completion and a 5 pp increase in vocational training completion.

\subsection{Trends in wage structure by skill level}

We use Social Security records to construct a measure of the lifetime returns to skill that youths could potentially observe. The measure is derived assuming that youths infer life-cycle effects from the contemporaneous age-skill wage distribution. The educational content of jobs in Social Security records can be inferred because each job is classified in 10 possible skill levels, where the first two correspond to collegesee "Appendix II" for details. The classification in Social Security permits classifying individuals in three skill levels: college level, mid-skill positions and laborers (workers in positions that, according to the employer, need no qualification). We compute median monthly earnings in cells defined by 10-year age bands (between 16 and 45 for laborers, between 26 and 45 for the rest), province, skill level and gender. We then take averages across those cell-specific median wages weighting by the number of young individuals in the province. Figure 2 plots, for each birth year cohort, the national averages of the ratio of the wage of unskilled workers to mid-skill ones ( $\frac{\text { Wunskilled }}{\text { Wmid_skill }}$ ) and the ratio of mid-skill workers to college $\left(\frac{\text { Wmid_skill }}{\text { Wcollege }}\right)$ when that cohort turned 17.

According to that measure, each cohort born between 1969 and 1976 would have observed by the age of 17 ratios between the median wages of unskilled- to skilled workers $\frac{\text { Wunskilled }}{\text { Wmid_skill }}$ and $\frac{\text { Wmid_skill }}{\text { Wcollege }}$ that were below those observed by the preceding cohort. For example, when the cohort born in 1969 turned 17 in 1986, the ratio between the median wage of unskilled workers and the median of mid-skill workers was $73 \%$. Seven years later, at the time of taking the decision of whether or not to finish upper secondary school, the 1976 cohort observed an equivalent ratio of $71 \%$. On the other hand, each cohort of males born between 1976 and 1988 has observed a secular increase in the wage of unskilled workers relative to mid-skill ones to achieve a level slightly above $80 \%$. The causes of the relative increase in low-skill wages are subject to debate, but some researchers have linked them to the increase in construction, a sector that employs disproportionally low-skilled workers-see Fig. $3{ }^{4}$ Thereafter, with the housing bust, the improvements of relative unskilled wages in the 90s stopped. Notice that the measure of relative wage used in this subsection is not fully representative of the opportunities of an average unskilled worker compared to an average skilled

\footnotetext{
${ }^{4}$ Changes in inequality in Spain during these last decades are notable in an international perspective. Bonhomme and Hospido (2017) report an increase in the p90/p10 ratio between 1988 and 1996 of 70pp and a decline of 17pp between 1997 and 2006. For instance, Juhn et al. (1993) document an increase of the ratio 90/10 of 30pp for the period 64-88 (and 10pp for the period 1982 and 1988 which is considered one of the periods with a higher rate of increase in wage inequality).
} 


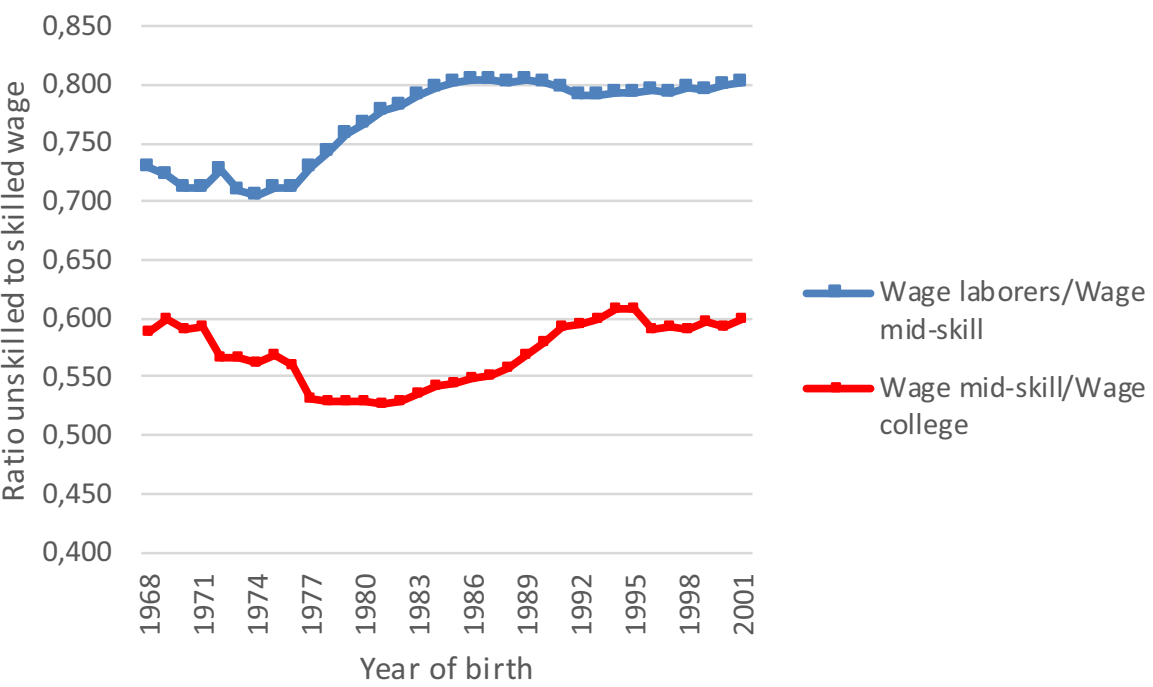

Fig. 2 Wage structure by skill level at age 17, by year of birth: Spanish males. a. Wages of laborers are medians among group 10 workers aged 16-45 years in province year. We take medians in three age cells (16-26, 26-35, 35-45) and average them. b. Wage of mid-skill workers are medians among groups 3-9 of workers aged $25-45$ age in province year. We take medians in two age cells and average them. c. Wages of college workers are medians among groups 1-2 of workers in 25-45 age in province year. We take medians in three age cells and average them. In the regressions, we use the cohorts born between 1969 and 1984. Source: Social Security Registers: 1989-2018

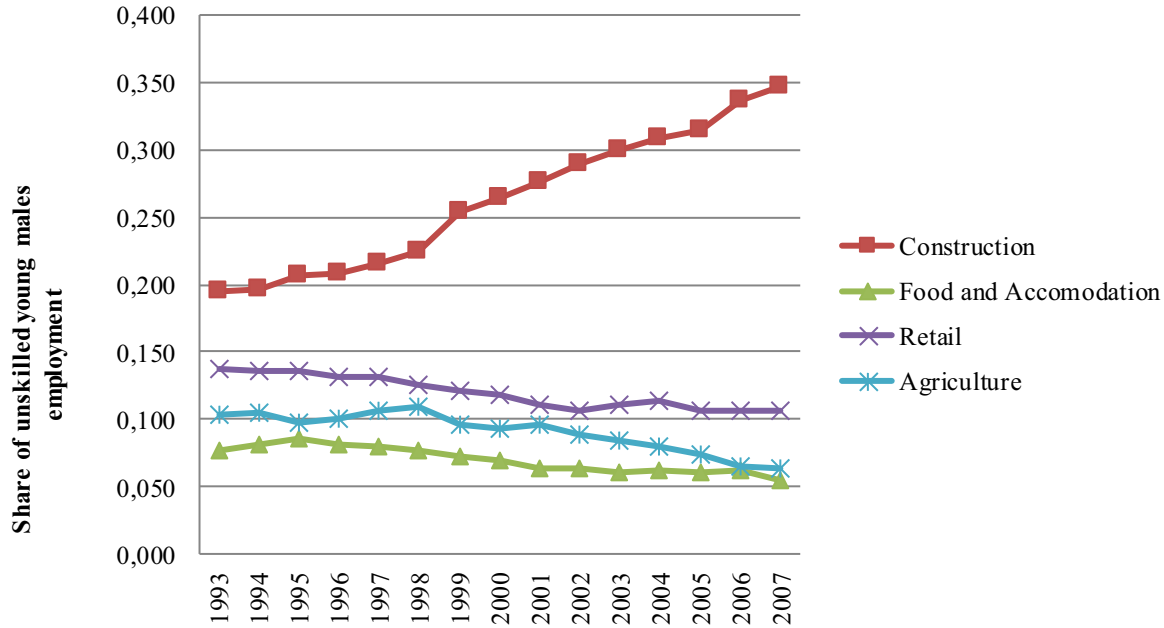

Fig. 3 Main industries employing unskilled youth, males. Source: Spanish Employment Survey (EPA): Waves 1993-2007. Unskilled youth defined as those with basic schooling or less.

worker since wages are observed only for those who worked. In the following section, we will discuss better alternatives. 
The remainder of this study uses several methods to assess whether or not the evolution of wages observed at age 17 may have caused the trends in schooling attainment depicted in Fig. 1a.

\section{The schooling choice and measurement of wages}

The dual structure of the Spanish educational system led us to take into account three skill levels (unskilled, vocational training and academic track) and the corresponding 3 wages. ${ }^{5}$ A priori it is not clear which track of post-compulsory education should be mostly affected by changes in different parts of the wage structure. There are several options to model those decisions. The first is to rank the AT, the VT and the compulsory levels by an unidimensional measure of ability, using an ordered Probit. That specification imposes that a change in the ratio of $\frac{\text { Wunskilled }}{\text { Wmid_skill }}$ affects marginal decisions between "adjacent" schooling levels (i.e., compulsory vs vocational training and vocational training vs academic). However, the basic trends in Fig. 1a and b suggest that relevant changes occurred not among such "adjacent" levels of schooling. Consider the case of males. The cohorts born between 1969 and 1976 experienced a linear decrease in the fraction of individuals completing at most compulsory schooling, until the level attained by 1976 cohort (38\%) stagnated for the next ten cohorts. Similarly, the percentage of individuals completing college at 25 increased among cohorts born between 1969 and 1976 and stagnated afterwards, while the fraction in vocational training experienced no noticeable trend. The shifts in both extremes of the distribution of schooling suggest using models that permit estimating separate responses of compulsory vs vocational and compulsory vs college to changes in the (perceived) wage structure. A second objection to use a ranking based on unidimensional ability is that the supply of skills differs among the AT (more centered on abstract tasks) and the vocational one (more centered on service or routine tasks). Both reasons lead us to model educational choices using a multinomial logit model. The cost is, of course, imposing the assumption of independence of irrelevant alternatives.

The relevant measures of $\frac{\text { Wunskilled }}{\text { Wmid_skill }}$ and $\frac{\text { Wmid_skill }}{\text { Wcollege }}$ deserve discussion. One option is to directly elicit the wage expectations of young adults (Delavande and Zafar 2019; Beffy et al. 2009; Manski 1993). A second option is to use contemporaneous average wages by skill level in the relevant local labor market: Manski (1993), López-Mayán (2010), Cameron and Taber (2004) or Buchinsky and Leslie (2010). ${ }^{6}$ The latter strategy assumes that youths take the wage of contemporaneous adults as indications of the wage the young adult would have if that level of skill were chosen. Nevertheless, contemporaneous wages are likely to be determined by the relative scarcity of unskilled labor. Studies of the evolution of the wage structure by Card and Lemieux (2001) or Carneiro and Lee (2011) emphasize that the relative supply of workers with different

\footnotetext{
5 In principle, one could also divide AT into high school and college. However, in the Spanish case most students who enroll in post-compulsory high school complete college; hence, we pool both levels together.

6 The papers differ in scope. For example, Cameron and Taber are mostly interested in obtaining exogenous variation in the college enrollment decision. Buchinsky and Leslie are interested in feeding a structural model of schooling with youths' estimates of the future evolution of wages, that they suggest is formed by observing by the structure of current and past wages and subsequently updated using VARs for each centile.
} 
skill levels determines versions of the ratios $\frac{\text { Wunskilled }}{\text { Wmid_skill }}$ and $\frac{\text { Wmid_skill }}{\text { Wcollege }}$. Secondly and, as mentioned above, it is not obvious which measure of relative wages young adults actually observe when taking their decisions about human capital investments. An ideal measure of incentives should be (a) observable by the youth and (b) capture primarily demand factors-rather than relative changes in the supply of unskilled workers. In the remainder of the paper, we exploit the prevalence of binding collective agreements at the province-sector level in the Spanish economy to obtain measures of $\frac{\text { Wunskilled }}{\text { Wmid_skill }}$ and Wmid_skill $\frac{\text { We }}{\text { Wcollege }}$. We then use the time series and the province-level variation of $\frac{\text { Wunskilled }}{\text { Wmid_skill }}$ and $\frac{\text { Wmid_skill }}{\text { Wcollege }}$ to estimate the impact of returns to schooling on schooling attainment.

\section{The data}

\subsection{Main datasets}

We use two different samples drawn from the 1992-2009 waves of the Spanish Labor Force Survey "Encuesta de Población Activa" (EPA), the Spanish equivalent to the Current Population Survey in the USA. The survey is conducted by the Spanish Statistical Institute, and it is representative of the Spanish population and interviewing some 20,000 households every quarter. The EPA tracks information about each member of the household above 16 within each household for up to six quarters, providing detailed information about demographics, educational attainment and labor market status.

The EPA is released in two main forms. The first is as a series of repeated cross sections where all individual identifiers are stripped off and it is not possible to track individual respondents (even though each individual still contributes up to 6 observations). We will term this sample the cross-sectional EPA. This sample contains detailed information on the educational attainment and the labor market and demographic outcomes of individuals above 16 years of age. In the case of young adults residing with their parents, the survey allows reconstructing parental characteristics. The Spanish Statistical Institute provided us with the exact age in years. The Spanish Labor Force Survey does not contain wages in the sample period we examine. As for province, we use that of current residence. We use the cross-sectional EPA to study the evolution of schooling attainment at later ages, that we set at 25 because the distribution of schooling attainment does not change much after that age.

The second sample contains exactly the same individuals as the former one, but allows the identification of each individual across waves and thus permits longitudinal analysis. We refer to this sample as the longitudinal EPA. In this case, household identifiers are stripped off, and information about schooling or demographics is given in a coarser way: age is grouped in five year bands and educational level is given with much less detail. Still, the dataset is very useful to study the dynamics of school to work transitions. Table 1 presents the summary statistics. 
Table 1 Summary statistics. Source: Panel A: Spanish Labor Force Survey (EPA): 1995-2009 (crosssectional version). See Table 12 for the definition of the concepts. Sample of male Spanish citizens that turn 25 in the year of the survey. Panel B: Spanish Labor Force Survey (EPA): 1993-2002 (longitudinal version)

$\begin{array}{ll}\text { Full sample } \quad \text { Lives with parents } & \begin{array}{l}\text { Not living with } \\ \text { parents }\end{array}\end{array}$

(3)

\begin{tabular}{|c|c|c|c|}
\hline Basic schooling & .407 & .375 & .607 \\
\hline Vocational training & .223 & .228 & .196 \\
\hline High school & .166 & .175 & .111 \\
\hline College & .202 & .220 & .085 \\
\hline \multirow{2}{*}{$\begin{array}{l}\text { Ratio low-skill wage over mid skill at } \\
17\end{array}$} & .713 & .7138 & .714 \\
\hline & $(.0514)$ & $(.051)$ & $(.051)$ \\
\hline \multirow{2}{*}{$\begin{array}{l}\text { Ratio mid-skill wage over high skill } \\
\text { at } 17\end{array}$} & .60 & .601 & .595 \\
\hline & $(.075)$ & $(.0752)$ & $(.069)$ \\
\hline \multirow{2}{*}{$\begin{array}{l}\text { Ratio of unemployment rate low skill } \\
\text { over mid-skill youth at } 17\end{array}$} & 2.180 & 2.176 & 2.223 \\
\hline & $(.506)$ & $(1.3746)$ & $(.516)$ \\
\hline \multirow{2}{*}{$\begin{array}{l}\text { Ratio of unemployment rate mid skill } \\
\text { over high skill at } 17\end{array}$} & 1.379 & 1.375 & 1.403 \\
\hline & $(.502)$ & $(.4976)$ & $(.539)$ \\
\hline Lives with parents & .86 & 1 & 0 \\
\hline Mother has basic school or less & & .821 & - \\
\hline Mother has high school & & .088 & - \\
\hline Mother has college & & .083 & - \\
\hline \multicolumn{4}{|c|}{ Number of observations used to compute youth unemployment rate } \\
\hline \multirow[t]{2}{*}{ Basic school } & 822 & 816 & 857 \\
\hline & $(521)$ & (523) & $(507)$ \\
\hline \multirow[t]{2}{*}{ High school } & 701 & 702 & 698 \\
\hline & (538) & (589) & $(549)$ \\
\hline \multirow[t]{2}{*}{ Vocational training } & 500 & 500 & 512 \\
\hline & $(310)$ & (308) & $(309)$ \\
\hline \multirow[t]{2}{*}{ College } & 757 & 754 & 774 \\
\hline & $(511)$ & (508) & $(524)$ \\
\hline \multicolumn{4}{|c|}{ Number of observations used to compute youth wages-Social Security records } \\
\hline Low skill & 598 & 595 & 616 \\
\hline Mid skill & 1462 & 1454 & 1507 \\
\hline High skill & 454 & 453 & 461 \\
\hline Number of observations & 41,697 & 35,521 & 6176 \\
\hline
\end{tabular}


Table 1 continued

Full sample

(1)
Lives with parents

(2)
Not living with

parents

(3)

Panel B: Summary statistics of longitudinal sample Waves 1993-2002

Enrolled in $t$, enrolled in $t+1$

.868

Enrolled in $t$, not enrolled in $t+1$ not .058 working

Enrolled in $t$, not enrolled in $t+1$ working

Number of observations:

18,375

\subsection{Information on wages}

We rely on out-of-sample information to construct measures of the wages that a young adult would use to form expectations about earnings in different education paths. As stated before, actual average wages suffer from the typical endogeneity problem between developments in wages and labor supply of youth. Moreover, our prior is that it is a measure that is difficult to be observed by youth, because it would require the student to have access to specific data on wages. Therefore, we opted for another measure of wages, ${ }^{7}$ based on collective agreements. This second measure can be directly observed with no need for accessing any data or making any calculations. Also, we will argue below that bargained wages are not affected by the endogeneity problem between wages and youth labor supply.

\subsubsection{Measures based on bargained wages in industry-level collective agreements}

Our measure of wages draws from the Registry of Collective Agreements between 1990 and 2009. In Spain, 75\% of workers have working conditions and wages determined by some collective agreement. These agreements are the result of a bargaining process between unions and employer federations. Most agreements have province-industry coverage, but there are some with higher (national) or lower (firm specific) coverage. During the sample period, firm-level agreements were subordinated to industry ones, so they could only improve working conditions beyond what was stated in the industrylevel agreement. Most of the industry-level agreements are negotiated by a small set of nation-wide trade unions and employer federations.

Collective contracts in Spain are automatically extended to all employers and employees under the scope of the agreement and the clauses included are legally binding. These contracts set a minimum wage for each skill level and thus generate an implicit wage structure by skill level during the life of the agreement (which typically lasts for 3 or 4 years). The definition of skill groups in the Registry of Collective Agreements is the same as in that in the Social Security records. Collective agreements get the same publicity as an Act from the Parliament would get, and it is

\footnotetext{
7 We report results on observed wages in Sect. 6.1.
} 
Table 2 Correspondence skill groups-schooling group

\begin{tabular}{llll}
\hline & $\begin{array}{l}\text { Skill groups } \\
\text { Social Security definition }\end{array}$ & Our notation & Schooling \\
\hline 1 & College graduates & High-skill & College \\
2 & $\begin{array}{l}\text { 2-Year college degree } \\
\text { Managers }\end{array}$ & Mid-skill & $\begin{array}{c}\text { Vocational training/upper } \\
\text { secondary }\end{array}$ \\
3 & Clerical workers, no college & & \\
4 & degree & & \\
5 & Clerical workers, rest & & \\
6 & Supporting clerical staff 1 & & \\
7 & Supporting clerical staff 2 & & Basic schooling \\
8 & Craftsmen, 1 & not used \\
9 & Craftsmen, 2 & Unskilled & \\
10 & Laborers & not used & \\
11 & Workers below the age of 18 & &
\end{tabular}

compulsory for the unions and employer federations to register their terms and conditions at the Ministry of Labor. The registry contains information about the industrial and geographical coverage of the agreement, the wage growth for a particular period as well as the month and year of signature. We focus on agreements with coverage at the province-industry level, that cover 54\% of workers in Spain. ${ }^{8}$ Between 1993 and 2001, the registry contains information about the wage levels for each of the skill groups in Table 2, and that is the information we use to construct our preferred measure of earnings. The concept we use is the "base wage", that excludes any premia linked to tenure on the job, age or performance and is closely linked to entry wages. We were unable to construct the wage measure for all provinces because not all provinces and industries have an agreement or some of the agreements did not register the levels of agreed wages. Hence, out of the 50 provinces, we only use 30 . The 30 provinces we use account for $76 \%$ of male employment in a $4 \%$ sample of Social Security records in November 2000. ${ }^{9}$

The structure of wages by skill settled within each collective agreement has not varied much over time. Nevertheless, the fact that skilled and unskilled young males work in different industries and that wage growth has evolved differently across indus-

\footnotetext{
8 See Card and de La Rica (2006) or Izquierdo et al. (2003). Actually, the 54\% estimate may be an underestimate as, during the sample period, firm-specific contracts cannot set lower wages than the corresponding province-sectoral agreement.

9 We cannot use Albacete, Avila, Badajoz, Burgos, Ciudad Real, Cordoba, A Coru ña, Cuenca, Guadalajara, Huelva, Huesca, Leon, Navarra, Ourense, Asturias, Palencia, Las Palmas, Salamanca, Segovia or Teruel. These provinces account for $24.5 \%$ of the population of male employees in October 2000. Employees in the excluded provinces are slightly younger than those included ( $34.75 \mathrm{vs} 35.59$ ). Their degree of qualification is similar to that of workers in included provinces. In the excluded provinces, $8 \%$ of male workers have a college degree and $20 \%$ are laborers, while in the included provinces the percentages are 10 and $18 \%$, respectively. Median base income in the included provinces was 1099 euro, while in the excluded ones was 955 euro (13\% lower).
} 




Fig. 4 Main industries employing skilled youth, males. Source: Spanish Employment Survey (EPA): Waves 1992-2008. Skilled youth defined as those with high school or more

tries generates variation in the returns to skill. For example, workers below 40 years of age and with basic education-or less — work mainly in construction (20\% in 1995), retail (14\% in 1995) and agriculture (10\%) (see Fig. 3). On the other hand, males with high school or more worked mainly in services (in particular, services to industry and education and health are the most typical destinations). While workers with upper secondary schooling or higher also work in construction, they do so to a lesser extent than unskilled young adults (less than $10 \%$ for all the period-see Fig. 4).

The second reason to focus on industries to construct wage levels is that wages increased differently across industries. The average wage growth in the construction collective agreements has experienced a markedly procyclical behavior (see Fig. 5). Right after the early 90s recession, unions and employer federations in the construction sector bargained yearly wage increases below the rest of the industries in 1994. Nevertheless, as the expansion evolved, the average wage in construction grew between 50 and 75 basis points more than in the rest of the industries. The previous two facts imply that, holding the share of unskilled and skilled workers constant in construction and in the rest of industries, the overall wage increase in construction relative to services is likely to mechanically increase relative low-skill wages.

Using the previous two facts, we partially adapt the strategy in Bartik (1991) or Gould et al. (2002) to construct measures of skill-specific local labor market opportunities. Bartik (1991) predicts the part of regional labor market outcomes that is due to national changes in demand by interacting initial industrial specialization in the region with the nationwide evolution of the wage in that industry. In our case, instead of using aggregate wage levels (or wage growth) to measure the opportunity cost of studying, we use province-sector-skill-specific wage floors as settled in collective contracts. As 


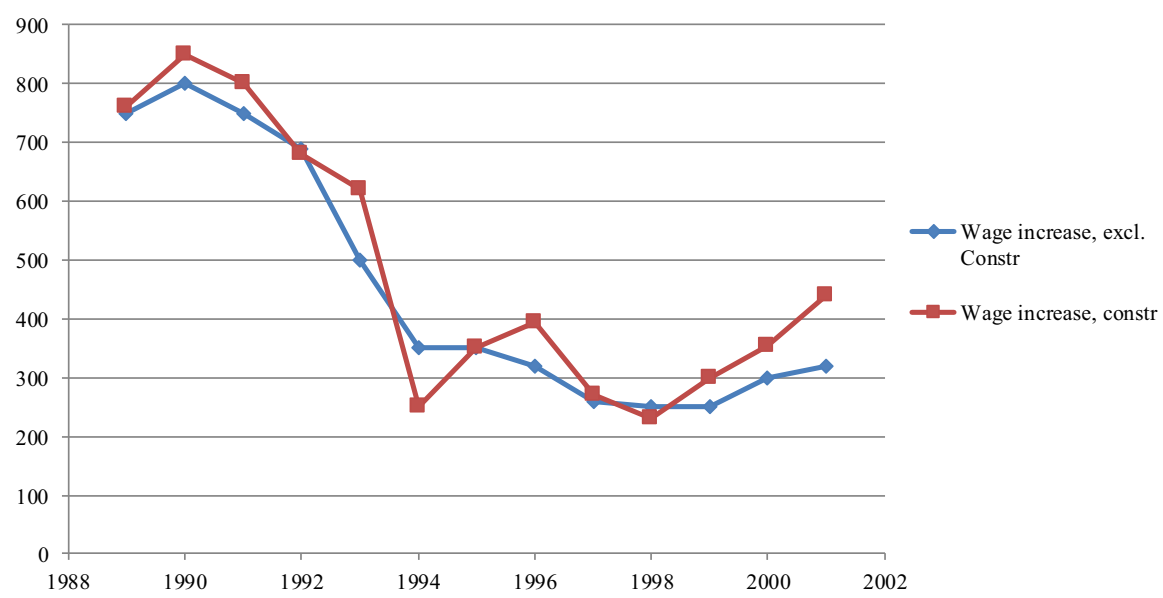

Fig. 5 Bargained nominal wage growth in construction and the rest of industries. Source: Registry of Collective Agreements 1990-2001

we document below, one of the advantages of using such wage floors is that the wages of unskilled young males bunch around that point. Hence, the evolution of the wage structure as derived from those wage floors can potentially be observed by the youths. 10

We construct proxies of the wages of workers with college education using the "base wages" of the first and second contribution groups (groups 1 and 2 in Table 2). We measure the wages of unskilled workers using the "base wage" of laborers (group 10 in Table 2). For the group with intermediate education, we use the collective agreement wage of group 3 (administrative workers). ${ }^{11}$ The measure of skill-specific wages we use is the following:

$$
\bar{W}_{s, p, t}=\sum_{j=1}^{j=5} \pi_{s, j, p, 1995} \bar{w}_{s, j, p, t}
$$

where $j$ indexes industries, $p$ indexes the province and $t$ indexes time. $\bar{w}_{s, j, p, t}$ is the wage bargained in industry $j$ for province $p$ and period $t$ for skill group $s$. For the main analysis, we use information on 5 industries. The first four are construction, retail, metal and services to the industry, which covered $73 \%$ and $50 \%$ of the employment of skilled and unskilled youth in 1992, respectively. ${ }^{12}$ We aggregate the wages of the rest of the industries in the province into a 5 th group. $\pi_{s, j, p, 1995}$ is the employment

10 Measures of the wage structure based on Bartik's instrument are free of compositional biases by definition. We discuss below to what extent wage floors reflect changes in the labor supply of youths.

11 Most values between groups 4-9 are missing in the collective agreements database and that is the reason why group 3 is the only one used.

12 We do not separate the wages of the accommodation and food services industry because there were more wage levels missing than in the rest. The industry employed about $2.4 \%$ and $6 \%$ of skilled and unskilled male youths, respectively. Nevertheless, when we use a sample of females, we do consider the industry separately, as it is an important employer of unskilled females. 
share of the industry in a province-age-education group as of 1995 . The temporal variation of industry share of youth employment is likely to be determined by the relative supply and demand of unskilled workers and may thus reflect factors other than the opportunity cost of studying. Hence, we fix the province-specific weight using the averages of 1992-1995 from the Spanish Labor Force Survey (cross-sectional EPA). ${ }^{13}$

\subsection{Do collective agreement wages reflect observable economic opportunities of young adults?}

We present three pieces of evidence, suggesting that the relative variation in wages bargained in collective agreements does reflect the opportunity cost of studying after the compulsory age. Firstly, we document that the wages settled for unskilled workers actually bind, as there is substantial concentration of actual wages of young workers around the levels bargained in collective agreements (at least for construction). Secondly, the variation over time of bargained wages responds more to the labor market tightness of workers older than 40 years of age, than to that of young adults. Finally, we show that changes in our measure of available opportunities by youth and actual wages are correlated.

\section{Accumulation of wages at the level settled by collective agreements}

We document the bite of collective agreements by plotting the distribution of nominal monthly wages of unskilled young construction workers in the four largest Spanish provinces in the Social Security sample: Barcelona, Madrid, Alicante and Valencia. We present histograms with distributions of nominal monthly wages in 1993 (a recession year at the beginning of the sample) and in 2000 - an expansion year. ${ }^{14}$ Visual inspection of Fig. 6a and b suggest the following conclusions.

Firstly, minimum wages of laborers in collective agreements do vary across provinces. The minimum wage was 779 euro in Barcelona in 1993, while it was 650 in Madrid in the same year. Similarly, it was around 690 euro in Alicante, but 623 in neighboring Valencia. The distribution of actual wages reflects those gaps. There is substantial mass of wages in Madrid below the minimum in Barcelona and the same happens with the adjacent provinces of Alicante and Valencia.

Secondly, there is accumulation of wages at or close to the province-specific minimum wage level. The degree of accumulation was high in Madrid in 1993-where 8\% of laborers get the collective agreement minimum wage and about $40 \%$ of laborers get a wage that is between the minimum and $10 \%$ above that minimum. However, the

\footnotetext{
13 The skill groups used to compute the incidence of the industry in the province are defined in terms of schooling, not of the skill levels contained in Social Security records. While it could be argued that the appropriate measure of $\pi_{s, j, p, 1995}$ would measure the province share of young males working in the industry defined by skill level, data-related problems prevent us from doing so. Because of its sampling schedule, Social Security records are representative of the working population only after 2005 . Hence, information from earlier years would not necessarily reflect the situation back in 1992-1995. Hence, we define three groups: compulsory or less, vocational training and upper secondary schooling and college.

14 Due to a limited sample sizes, we show the 1995 wages for Alicante and Valencia, rather than the 1993 ones. We use monthly wages in the months of October to December. Histograms are computed using male workers between 18 and 35 years of age, who work full time and have been in the firm for at least six months. The sample sizes to compute the histograms oscillate between 297 cases in Alicante in 1995 and 1111 cases in Barcelona in 2000.
} 

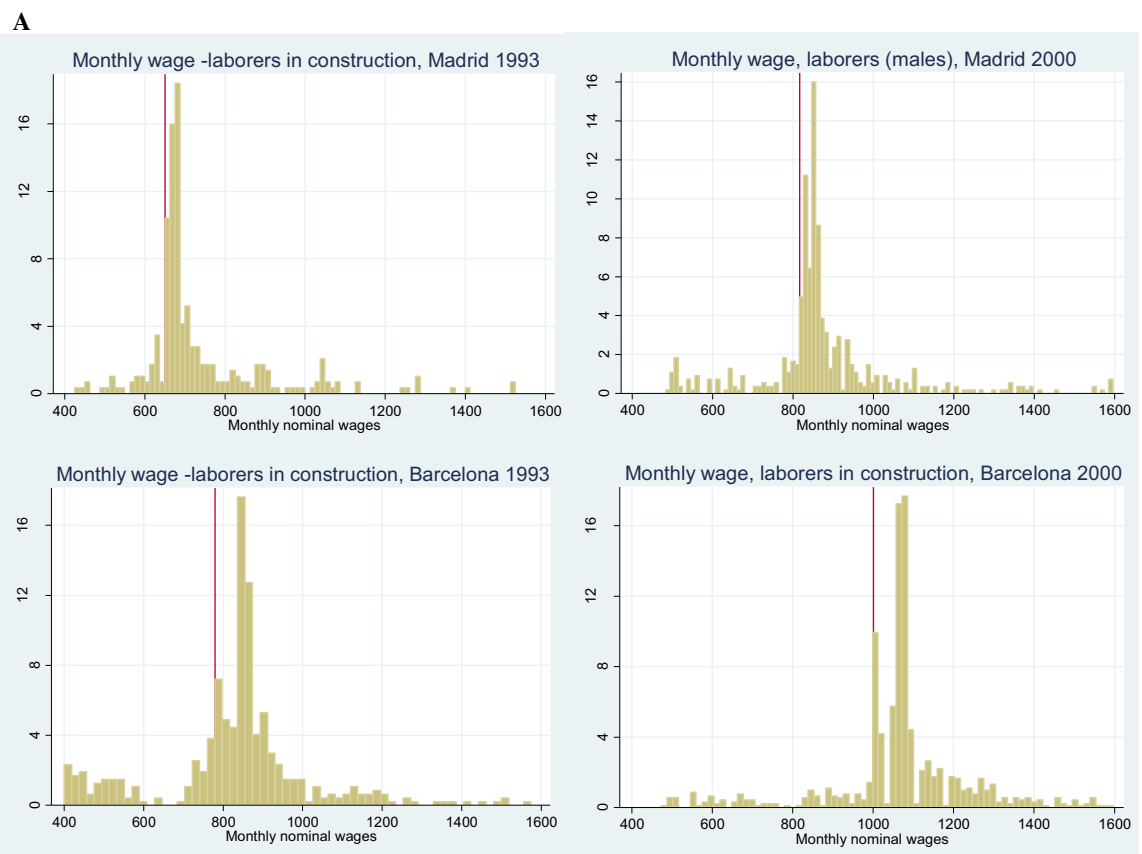

Fig. 6 Histogram of wages from social security records in selected provinces: a Madrid and Barcelona, b Alicante and Valencia. Histograms of wages of laborers (the group with lowest qualification) between 18 and 30 years of age. The distribution covers the range 400-1600 euro. The vertical line depicted represents the bargained wage for laborers in the collective agreement in construction. a The width of the bins is 19.6 euro in Barcelona and 12 euro in Madrid (1993), chosen so as the collective agreement wage coincides with the starting point of its bin. b The width of the bins is 12 euro in Alicante and 10 euro in Valencia (1993), chosen so as the collective agreement wage coincides with the starting point of its bin

accumulation is also noticeable in Alicante or Valencia (between 4 and $8 \%$ of laborers get the minimum wage).

Accumulation implies that a youth considering leaving the school system is likely to observe those wages - these are prevalent among other youths working in the sector. In the absence of information on how youths form their expectations about earnings in the event of dropping out, the concentration of wages around statutory minima suggests that the fact that these wages are both compulsory and minimum serve as a basis for taking his or her schooling decisions.

Finally, the figures show some degree of noncompliance-i.e., monthly wages below the statutory minimum. For example, Table 13 shows that the fraction of wages below the wage floor was high in 1993 (14.8\%) and lower in 2000 (8.9\%). Some of that slippage is due to the fact that some firms may not update their wages automatically but do so over the year-as well as particular labor contracts that may qualify for wages below the agreement minimum. In general, more than one-quarter of male laborers earn wages between their corresponding wage floor and $5 \%$ above that amount. The fraction has remained stable over the sample period.

Wage growth in collective agreements: 

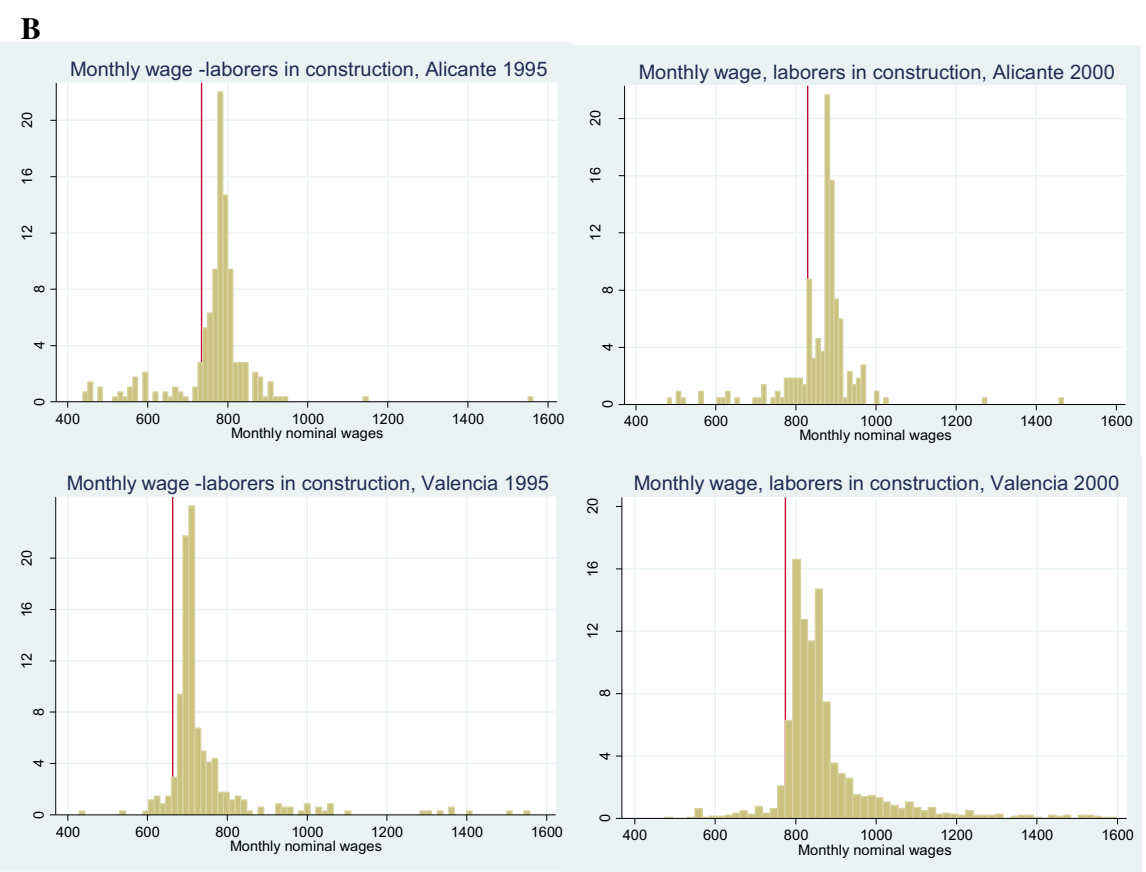

Fig. 6 continued

The identification strategy in our study relies in the time-series variation in industryspecific collective bargaining wages within provinces. A key assumption is that province-specific changes in bargained wages respond little to province-specific shifts in the inflow of unskilled young adults. Models of wage bargaining typically assume that final wages depend on the outside opportunities of firms and workers, and stress the role of unemployment as an (inverse) measure of outside opportunities. Hence, to understand whose outside opportunities are taken into account in wage bargaining, we regressed wage growth on (one-year lagged) unemployment rates of unskilled workers in four age groups: 16-25, 26-35, 36-45 and 46-55. The regression also includes province and year dummies. The former control for provincial long-run specialization, and the latter for macro factors that affect wage growth (such as the inflation rate). We lag the unemployment rate to mitigate simultaneity biases.

Table 3 presents the results for 4 different agreements: construction, retail, metal and a composite of the rest of the agreements. All regressions are weighted by the number of workers covered by the agreement. The result is column 1 row 1 is -239 . That is, a 10 percentage points increase of the provincial unemployment rate of workers between 16 and 25 years of age reduces wage growth in construction by .239 percentage points (standard error: .18). The estimate in row 4 column 1, measuring wage responses to unemployment among the $46-55$-year old is -755 . That is, increases in unemployment rate among individuals between 46 and 55 years have three times the impact on wage growth than that of 16-25 years of age. The estimates across industries generally suggest a much larger wage response to the unemployment rate of workers over 35 
Table 3 The determinants of wage growth in collective agreements: lagged unemployment rate

Dependent variable: yearly wage growth in the agreement (percentage points * 100)

Construction Retail Metal Rest of industries

(1) (2) (3) (4)

\begin{tabular}{lllll}
\hline Covariates: 1-year lagged unemployment rate & & \\
1. Urate 16-25 years old & -239.56 & -18 & 9.981 & 92.00 \\
& $(184.17)$ & $(148.70)$ & $(181.079)$ & $(150.16)$ \\
2. Urate 26-35 years old & -10.22 & 112 & -130.88 & -9.722 \\
& $(298.77)$ & $(238)$ & $(305.715)$ & $(241.36)$ \\
3. Urate 36-45 years old & -600.41 & -684.09 & 62.004 & -346.67 \\
& $(343.5)^{*}$ & $(276.11)^{* *}$ & $(336.82)$ & $(276.00)$ \\
4. Urate 46-55 years & -755.62 & -107.47 & -358.558 & -404.47 \\
& $(312.9)^{* *}$ & $(250.37)$ & $(308.055)$ & $(254.13)$ \\
Number of observations & 323 & 342 & 329 & 350 \\
$R$-squared & .337 & .31 & .312 & .336
\end{tabular}

Sample: Merged data set of Spanish Employment Survey and Registry of Collective Agreements The measure of unemployment rate refers to adults with education at the primary level of less and varies between 0 and 1

Wage growth is measured in percentage points multiplied by 100 , i.e., 1000 reflects a $10 \%$ wage increase The estimation method: weighted least squares, where weights are the number of workers in the province The unit of observation is the year-province. Sample 1995-1999. Additional regressors are province and year dummies

than to the unemployment rate of unskilled young workers. We infer from the pattern of estimates that bargained wage growth does not primarily reflect the economic condition of unskilled young workers.

\section{Bargained and actual wages}

The third piece of evidence shows the link between wages in collective agreements and the median of actual wages perceived by unskilled workers relative to the median of actual wages perceived by mid- and high-skilled workers.

Table 4, row 1 shows estimates of the impact of the ratio of the wages of laborers on mid-skill groups on the wage bargained for laborers in the province for the five industries considered: construction, metal, services to industries, retail and rest. Each province-year unit provides one observation, weighted by the number of workers in the province in the Social Security database (as that was the database used to compute median wages). All specifications include year and province dummies. An increase of 10 percentage points in our measure of the ratio of collective agreement wages between low- and mid-skill workers increases the actual ratio of unskilled-to mid-skill market by 1.87 percentage points. In Column 2, we examine which component explains the ratio of low- to mid-skill wages. The results suggest that the component associated 
Table 4 Actual wages and wages in collective agreements

\begin{tabular}{|c|c|c|c|c|}
\hline \multirow[t]{2}{*}{ Dependent variable } & \multicolumn{2}{|c|}{$\begin{array}{l}\text { Ratio of unskilled to } \\
\text { mid-skill wages (ages } \\
16-40 \text { ) }\end{array}$} & \multicolumn{2}{|c|}{$\begin{array}{l}\text { Ratio of mid- to } \\
\text { high-skill wages (ages } \\
25-40 \text { ) }\end{array}$} \\
\hline & (1) & (2) & (3) & (4) \\
\hline $\begin{array}{l}\text { 1. Wage laborers/wage mid-skill } \\
(\text { service }+ \text { construction }+ \text { retail }+ \text { metal }+ \text { rest })\end{array}$ & $\begin{array}{l}.187 \\
(.077)\end{array}$ & - & & - \\
\hline 2. Wage mid-skill/wage high-skill & - & - & $\begin{array}{l}.109 \\
(.052)\end{array}$ & - \\
\hline \multicolumn{5}{|c|}{ Decomposing the measure into its components, by industry } \\
\hline $\begin{array}{l}\text { 3. Construction } \\
(\text { share youth } * \text { wage laborers }) / \Delta\end{array}$ & & $\begin{array}{l}1.282 \\
(.289)^{* * *}\end{array}$ & & $\begin{array}{l}-.33 \\
(.225)\end{array}$ \\
\hline 4. Services to industries & & .316 & & -.07 \\
\hline$($ share youth $*$ wage laborers)/ $\Delta$ & & $(.276)$ & & $(.14)$ \\
\hline 5. Retail & & -.780 & & .281 \\
\hline$($ share youth $*$ wage laborers) $/ \Delta$ & & $(.281)^{* *}$ & & $(.131)^{* *}$ \\
\hline 6. Metal & & -.909 & & -.948 \\
\hline (share youth $*$ wage laborers)/ $\Delta$ & & $(.964)$ & & $(.718)$ \\
\hline 7. Rest of industries & & .08 & & .274 \\
\hline$($ share youth $*$ wage laborers)/ $\Delta$ & & $(.10)$ & & $(.097)^{* *}$ \\
\hline Constant & $\begin{array}{l}.569 \\
(.065)\end{array}$ & $\begin{array}{l}.60 \\
(.05)\end{array}$ & $\begin{array}{l}.49 \\
(.041)\end{array}$ & $\begin{array}{l}.523 \\
(.045)\end{array}$ \\
\hline Number of observations: & 339 & 339 & 303 & 303 \\
\hline
\end{tabular}

Each unit observation is a province-year unit. The dependent variable is the ratio of unskilled wages (laborers, according to the Social Security classification) and mid-skill levels (groups 3-8, in that same category). Covariates are bargained wages for the skill and industry level shown in each covariate. All specifications include year and province dummies. Standard errors clustered at the province level Estimation method: weighted least squares, where the weights are the number of workers between 16 and 41 in the province-year cell according to the Social Security records dataset

Denom is the weighted sum of skill-specific collective agreement wages (mid-skilled in Columns 1-2, high-skill in Columns 3 and 4)

$\Delta$ is the Average mid-skill wage in Column (2) and the Average wage in the top skill in column (4)

to construction has the largest coefficient in the low- to mid-skill ratio but has little explanatory power in the mid- to high-skill ratio. ${ }^{15}$

$\overline{15}$ Namely, we run the following regression:

$$
\frac{W_{\text {prov }, \text { low-skill, } t}}{W_{\text {prov, mid-skill }, t}}=\theta_{0}+\sum_{i=1}^{i=5} \theta_{i} \frac{\pi_{\text {prov }, i, 95}}{D_{\text {prov }, t}} \bar{w}_{\text {prov }, i, \text { lowsk }, t}+\gamma_{1, t} D_{t}+\gamma_{2, \text { prov }} D_{\text {prov }}+\varepsilon_{\text {prov }, t}
$$

where $\frac{W_{\text {prov,low-skill, } t}}{W_{\text {prov,mid-skill, } t}}$ is the ratio of low- to mid-skill wages in the Social Security records, $i$ indexes industries and $\bar{w}_{\text {prov, } i, \text { low }}$ are the wage levels of laborers in collective agreements. Finally, $D_{\text {prov, } t}$ is

$$
D_{\text {prov }, t}=\sum_{i=1}^{i=5} \pi_{i, 95, p r} \bar{w}_{i, \text { mid-skill }}
$$


Columns 3 and 4 show the results of a regression of the ratio of mid-to-skill wages on the same ratio based on collective agreements. Again, a 10 percentage points increase in the measure based on collective agreements increases by 1 percentage point the ratio of market wages.

\subsection{Methods}

We use two measures of educational outcomes $S_{i, p, t}$. The first one is short-run and measures transitions out from the educational system. The second is a longer-run measure of the final educational attainment at the age of 25 . We estimate reducedform versions of the following form.

$$
S_{i, p, t}=\alpha_{0}+\alpha_{1} \frac{\bar{W} \text { unskilled }}{\bar{W} \text { mid_skill }}+\alpha_{2} \frac{\bar{W} \text { mid_skill }}{\bar{W} \text { college }}+\mu_{p}+\theta_{t}+\varepsilon_{i, p, t}
$$

$\mu_{p}$ are local labor market fixed effects (province dummies), $\theta_{t}$ are time fixed effects and $\frac{\bar{W} \text { unskilled }}{\bar{W} \text { mid_skill }}$ and $\frac{\bar{W} \text { mid_skill }}{\bar{W} \text { college }}$ denote the wage structure that youths would observe at the age of 17 -when educational decisions are taken. ${ }^{16}$ We define three levels of schooling attainment $S_{i, p, t}$ by a young adult $i$ in a province $p$ at time $t$ : basic schooling (or less), vocational training or a joint outcome that lumps together secondary academic track and college. The vocational track and the academic track provide a very different set of skills to youth that complete them. As we found it very hard to rank those skills, we estimate the model as a multinomial logit—see discussion in Sect. 3. In addition, in most specifications we also show the results with a binary dependent variable that takes value 1 if the youth completed any degree beyond the compulsory one. Whenever we estimate variants of equation (2) we include province fixed-effects and, as a robustness in separate specifications, province-specific trends.

The coefficients of interest are those of the two measures of the returns to skill $\alpha_{1}$ and $\alpha_{2}$. The identification is obtained from changes across provinces and time in the ratios of unskilled to skilled wages when a cohort reaches the age of 17 .

Finally, family characteristics exhibited a steady improvement over the sample period. To control for those in some specifications, we select a sample of coresident young adults ( $86 \%$ of our sample lived with their parents at the age of 25). Namely, we control for dummies with the educational attainment of the mother and indicators of whether the mother and the father live in the household of the young adult.

\subsubsection{Sources of biases}

Wages settled in collective agreements respond to some workers' economic situation -see Table 3. If these are correlated with youths' perceived wages and schooling

\footnotetext{
16 In principle, it is not obvious that the ratios of wages in different skill levels are the best choice to measure the incentive to study - rather than, for example, the level of the wage. Nevertheless, as we use variation across provinces over time, by taking ratios of wages we mitigate problems related to inter-provincial differences in the cost of living (see Moretti 2013).
} 
decisions, the estimates would be biased. To address such concerns, we include controls for the contemporaneous unemployment rate of the youth by skill level. In particular, we introduce in some specifications the provincial unemployment rate of unskilled individuals youths between 26 and 35 years of age, between 36 and 45 and between 46 and 55. Secondly, we also experiment including additional controls for provincelevel trends. To the extent that the influx of new entrants is partly determined by the evolution of demography (larger cohorts at the province level), provincial time trends would net out such effects.

Thus far, we are interpreting changes in collective agreement wages as reflecting an outward shift of the labor demand curve at the industry level. Nevertheless, a second source of biases would arise if increases in collective agreement wages represent a movement along the demand curve, leading to employment destruction (such as the textbook model of the labor market predicts an increase in the minimum wage would do). In such case, increases in $\frac{\bar{W} \text { unskilled }}{\bar{W} \text { mid_skill }}$ measured by collective agreements would correlate positively with the growth in youth unemployment, possibly generating a downward bias in our estimates. ${ }^{17}$ Two notes are in order. In our setting, the increase in collective agreement wages has a component of industry demand that is most likely lacking in minimum wage increases. To assess to what extent this is a problem, we experiment with broader measures of economic incentives where we interact $\frac{\bar{W} \text { unskilled }}{\bar{W} \text { mid_skill }}$ with the ratio of unemployment rates between low-skill and midskill workers. Secondly, we also examine school to work and non-work transitions. If increases in collective agreement wages measure movements along the demand of labor curve, we should observe the same type of responses that Neumark and Wascher (1995) document: a higher chance of transition into non-work following an increase in low-skill wages.

\section{The response of schooling attainment to wages}

\subsection{Enrollment and school to work transitions}

We start by estimating the response of the decision to continue studying at ages 16-19 to changes in the structure of wages as set by collective agreements. Namely, we use longitudinal information on youths to examine if changes in the wage structure in the provincial collective agreements led youths to stop studying and start working during the five quarters that follow the first interview. Secondly, the most likely reason that leads youths to abandon school after a relative increase in low-skill wages is to start working. Hence, we also examine how a change in the wage structure affects three different transitions: staying in school, transiting from school to non-employment and transiting from school to employment.

\footnotetext{
17 Clark (2011) shows that unemployment in the UK correlates positively with enrollment. Neumark and Wascher (1995) show evidence, suggesting that increases in minimum wage increases increase the fraction of non-employed non-enrolled youth, as less jobs for unskilled youth become available. In such case, unskilled youth would not fully internalize second-round effects in unemployment of minimum wage increases.
} 
The sample is composed of male youths between ages 16 and 19 who are enrolled in primary education, high school or vocational training at the time of the first interview. We define a drop out as a change in the school enrollment status of a youth who is first observed in primary, secondary or vocational training. ${ }^{18}$ The wage structure at the beginning of the academic year is used as a regressor. Given the coarse information on education and age in the longitudinal EPA, our definition of dropouts includes young adults who have achieved either a high school or a vocational training diploma at the age of 18 or 19. Such definition is not fully consistent with the one used in subsequent sections (maximum degree completed at the age of 25). The dependent variable takes value 1 if the youth drops out and 0 otherwise. As in the rest of the paper, we estimate Probit models controlling for province and time fixed effects.

Table 5 column 1, row 1 presents the results of the regressions of school leaving on measures of the wage structure. An increase in the ratio of low- to mid-skill wages of 10 percentage points increases the chances of leaving the schooling system by 2.4 percentage points (standard error: .7), evaluated at a youth in Madrid who has born between 1976 and 1980. Columns 2-4 in Table 5 use a Multinomial Logit to assess alternative forms of school leaving. An increase of 10 percentage points in the ratio of low- to mid-skill wages increases the fraction of youths who drop out and work by 1.6 percentage points, while the fraction of youths who stop attending school and do not work increases by approximately half the magnitude: .8 percentage points. On the contrary, an increase in the ratio of mid- to low-skill wages does not affect much the chances of leaving the educational system.

In Panel B, we introduce province-specific trends to account for demographic or other factors that move slowly as well as the skill-specific unemployment rate of young adults. The results are not altered substantially by the inclusion of those covariates. The response of dropouts to a 10 percentage points increase in the ratio of low- to mid-skill wages is again 2.5 percentage points, and the estimate is different from zero at the $7 \%$ confidence level. The unemployment rate or the ratio of mid- to high-skill wages plays little role in any of those specifications.

Finally, we falsify the hypothesis that the estimates are indeed picking up the schooling dropout response to an increase in relative wages. We build on an idea of Aparicio (2016). As unskilled Spanish males work in construction but that unskilled females work in retail or food services, Aparicio estimates the impact of the construction boom on dropout rates by comparing the dropout rate of males and females. We conduct a similar exercise here, but incorporating that specialization pattern in the measure of the wage structure. Namely, we test if the ratio of unskilled to mid-skill wages faced by young males - heavily influenced by the role of construction in 1992 — affects the schooling decisions of females - who are unlikely to receive those wages. The estimates are shown in Panel $\mathrm{C}$ in Table 5 and suggest that the wage structure faced by males affects neither the dropout rate of females (see the negative and small coefficient in Column 1 in Table 5, Panel C) or the school-to-work transitions (Columns 2-4 in Table 5, Panel C).

\footnotetext{
18 We exclude from the sample those individuals who, during the 6-quarter length of the panel report more than one transition. For example, we exclude youths who are dropouts but subsequently report that they are enrolled again.
} 


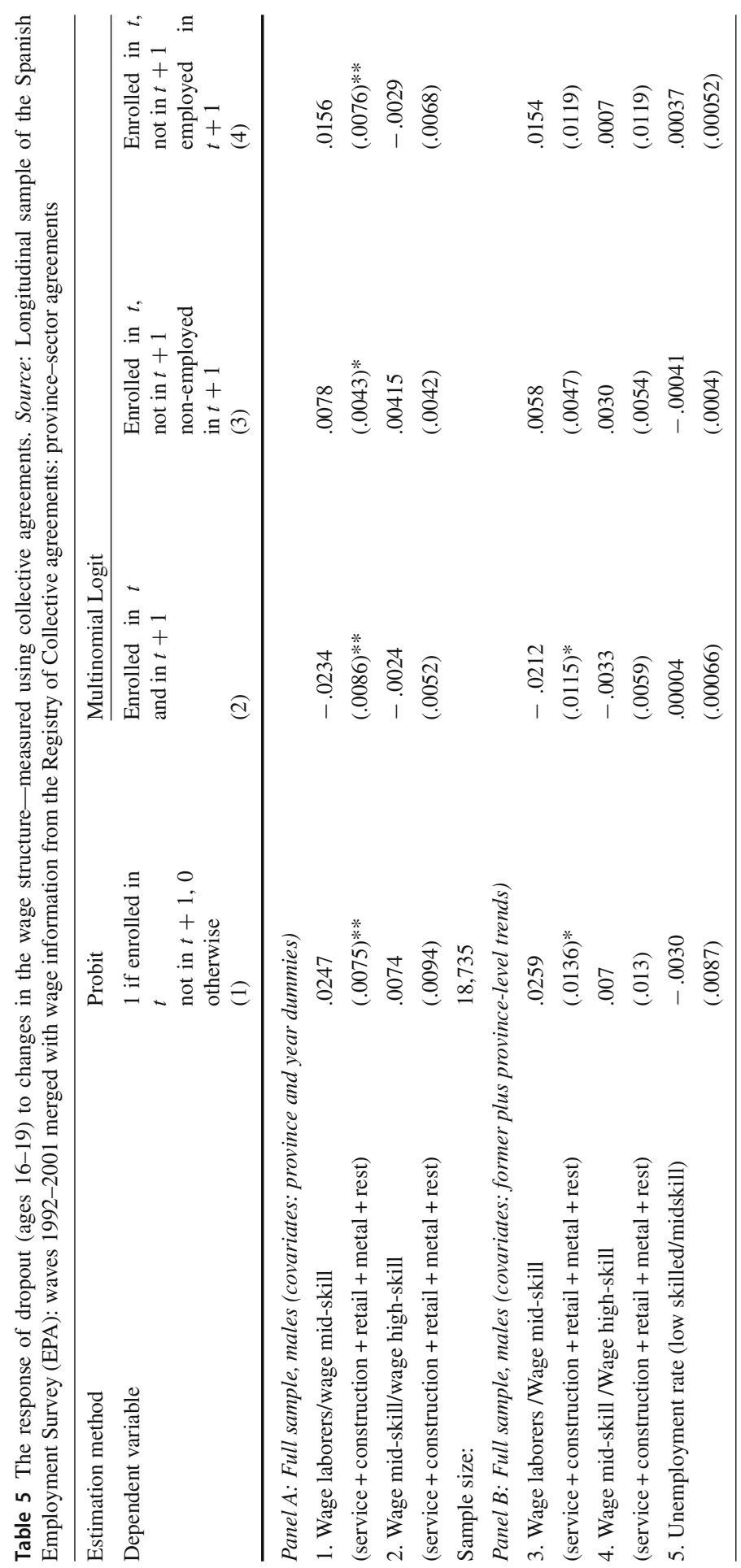









\subsection{Schooling attainment}

Table 6 shows the response of schooling attainment at age 25 to a $10 \%$ increase in the ratio of bargained wages in low-skill jobs relative to mid-skill (row 1) and the ratio of mid- to high-skill jobs (row 2), both observed at age 17. As in Table 5, the first magnitude measures the (inverse of the) returns to acquire at least some schooling. The second is the (inverse of the) returns to college: the ratio between mid-skill wages and the bargained wages of jobs that require college. All responses are evaluated for a young adult born in 1974, living in Madrid and, in Panels B-D, living with parents and whose mother has a high school degree.

Column 1 of Table 6 Panel A shows the response of the probability of completing any form of secondary schooling on both measures of the wage structure, estimated using a Probit. Cohorts that at age 17 observed a ratio of unskilled to mid-skill wages 10 percentage points above the provincial mean were 6.5 percentage points less likely to having completed any schooling beyond the compulsory one at the age of 25 . The standard error is 1.8 percentage points. The estimate is more precise than the comparable one in Table $5 .{ }^{19}$

In Columns 2-4, we show how the different forms of schooling attainment are affected by changes in the wage structure, now using a multinomial logit. The coefficient of the first row of Table 6, Panel A, column 2 is .055 (standard error: .015). That is, a cohort exposed at the age of 17 to a ratio of unskilled to mid-skill wages $10 \%$ higher than the provincial average is 5.5 percentage points more likely to attain only basic schooling and 6.5 percentage points less likely to finish the academic high school track than a cohort who faced at age 17 the average ratios in the province. That result is surprising since one might think that students in the vocational training track are less attached to the educational system than students of the academic track. López-Mayán (2010) successfully estimates a structural model of grade progression for the 1985 cohort, finding that students of vocational training are most sensitive to relative changes in the return to vocational training, computed with actual wages. A possible difference is that we use a measure of relative wages that is less sensitive to relative changes in the supply of unskilled workers if, for example, there were contemporaneous shocks in the labor supply of workers who would be observed high school students had the relative wages of unskilled workers in the province been lower. We discuss the issue in Sect. 6.1.

The impact on schooling attainment of our measure of the returns to college is shown in the second row of Tables 6 and 7 . A cohort exposed at 17 to a ratio of midskill wages to college wages $10 \%$ higher than the provincial average is 3.8 percentage points less likely to complete high school (standard error: $1.5 \mathrm{pp}$ ) and 3.6 percentage points more likely to finish vocational training. The result confirms that young adults engage in upper secondary schooling as a route to complete college. Holding constant

\footnotetext{
19 The magnitude of the estimate in Table 5, Panel A, row 1, column 1 (.025) is smaller than that in Table 6, Panel A, row 1, column $1(-.065)$. However, it is not obvious that both should coincide, as attending school between 16 and 19 and getting a secondary school degree by age 25 are different outcomes. Some students may respond to higher unskilled wages by working part-time while staying in the educational system as grade repeaters. The higher wages they faced at 17 may eventually result in a lower academic effort that eventually impedes completing secondary school—despite being formally enrolled at the age of 19 .
} 


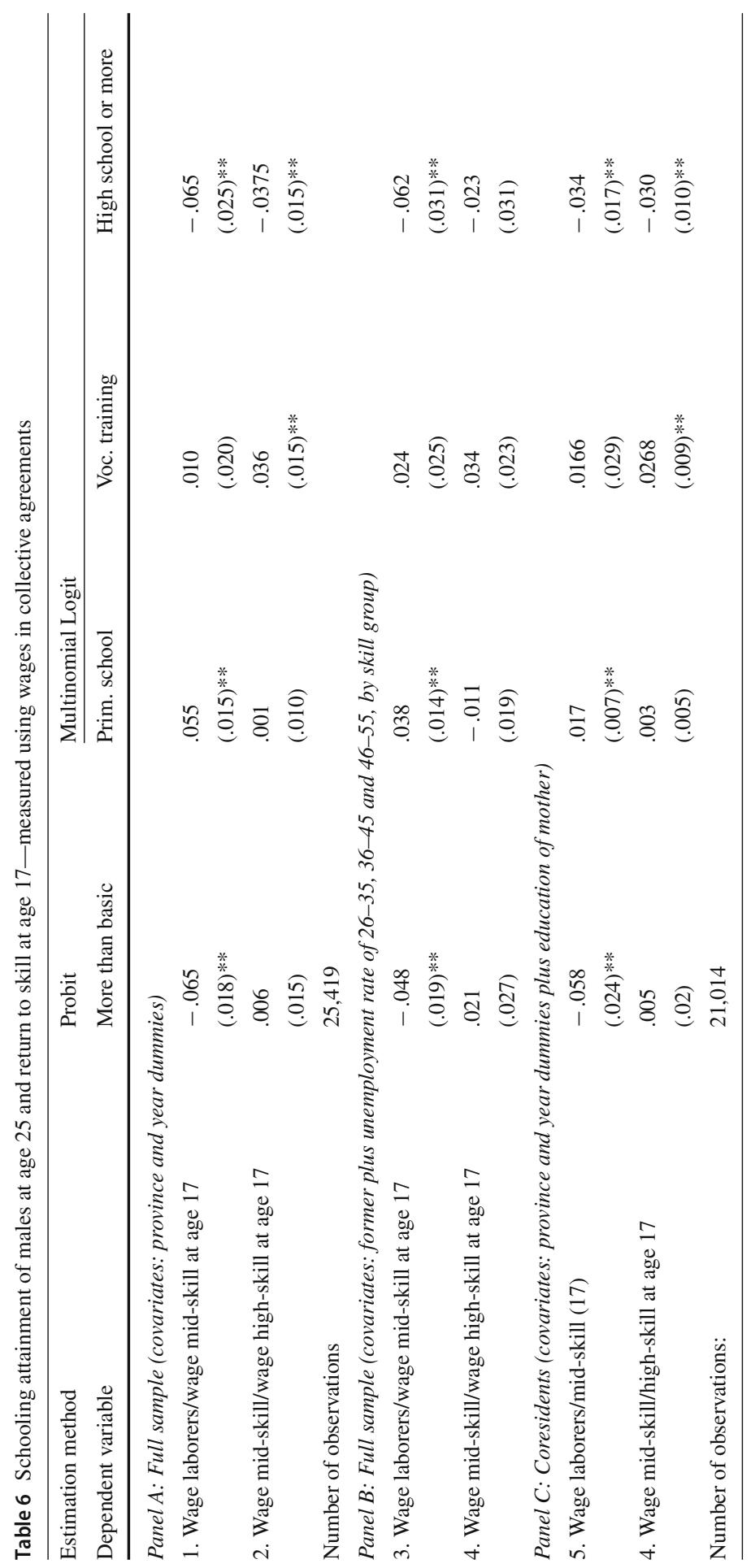




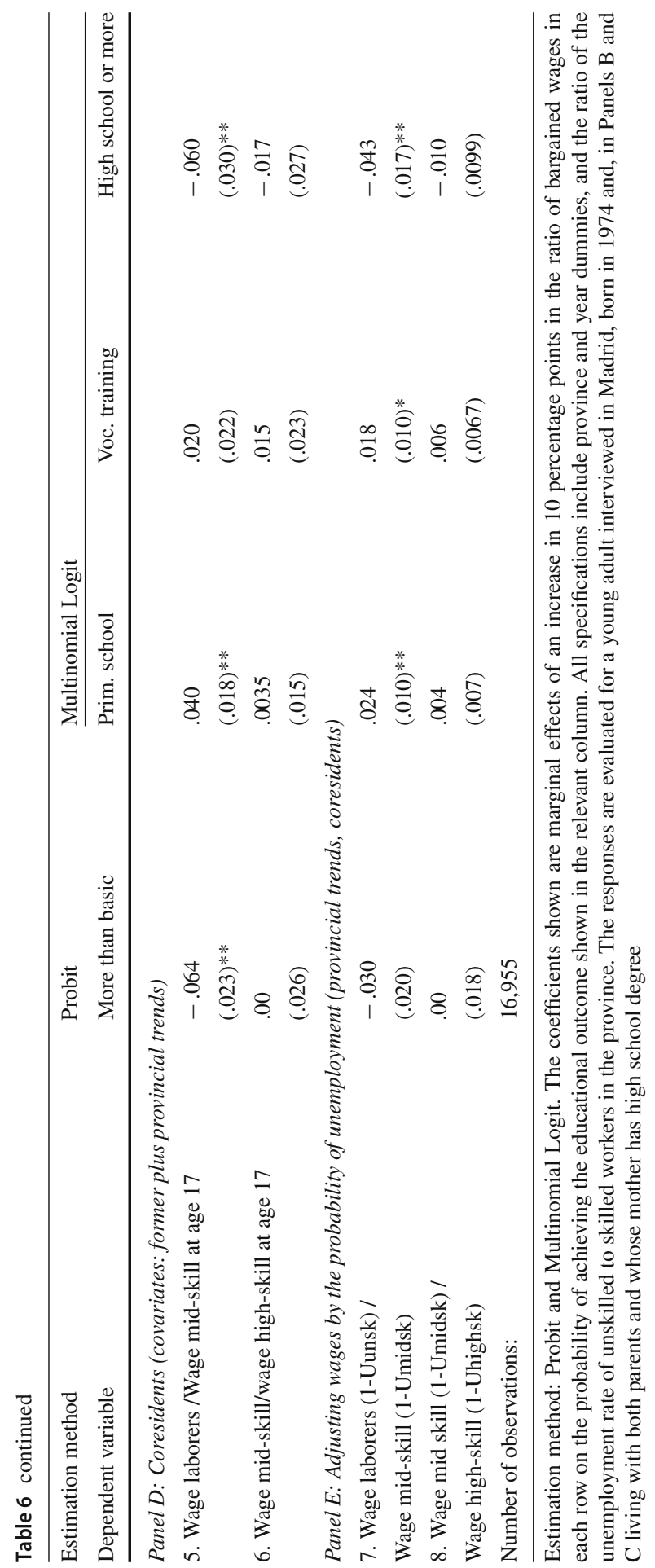




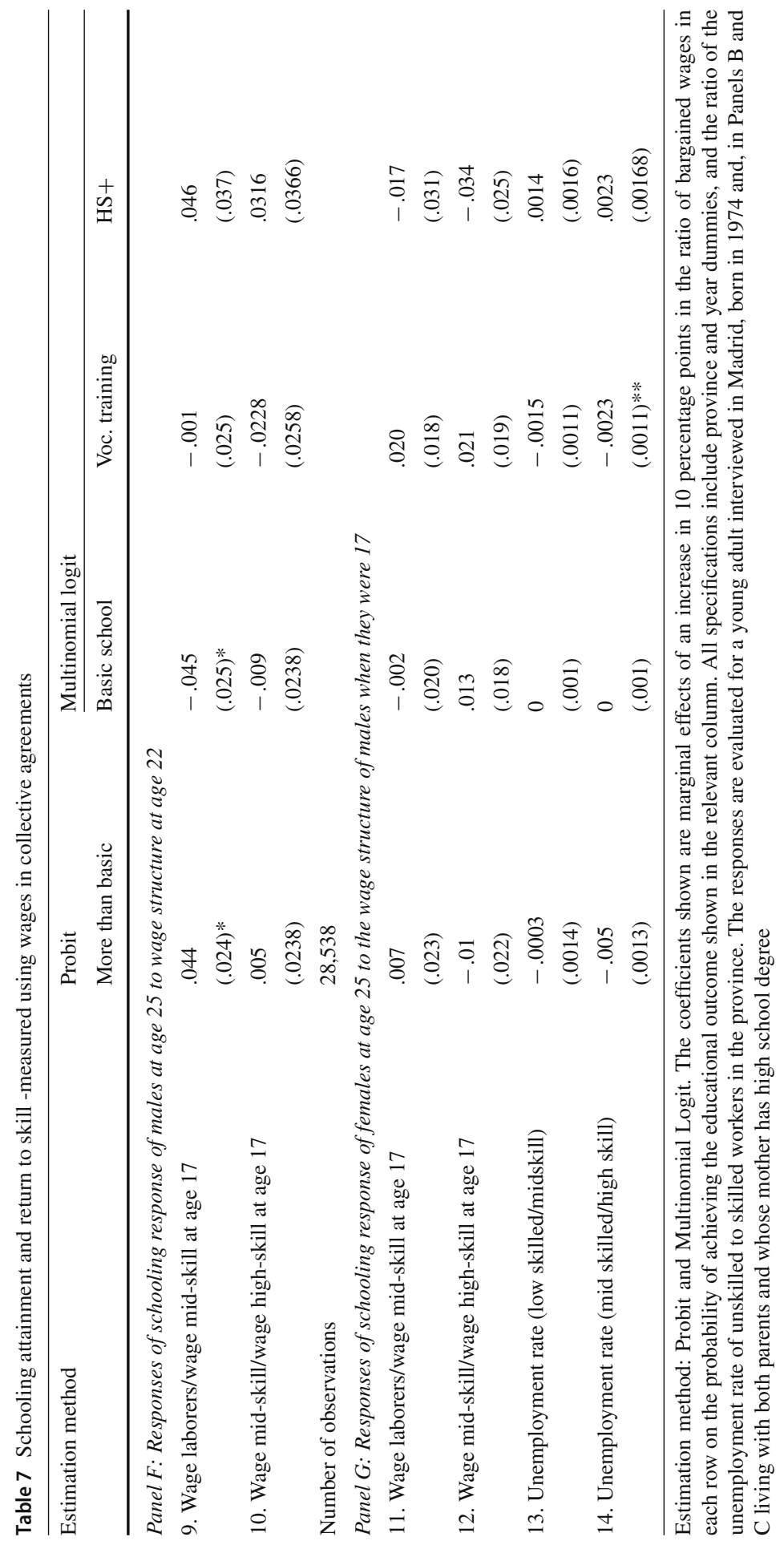


the ratio of unskilled wages to mid-skill ones, a fall in the returns to college does not affect the chances of completing primary schooling.

Panels B, C and D in Table 6 examine the robustness of the results in Panel A when we specify two other changes in the specification. The first model controls for the provincial unemployment rate of unskilled individuals in ages between 16 and 25, 26 and 35, 36 and 45 and 46-55. The other specifications limit the sample to coresidents and are thus able to control for parental background characteristics - or add province-specific trends. The main result indicating that an increase in the relative wage of unskilled workers leads affected cohorts to complete at most the compulsory schooling level at the expense of potential students of the high school academic track is robust to those changes in the specification. However, once we add provincial trends, we no longer find a statistically significant impact of the returns to college on the share of young adults completing either upper secondary or vocational training. A possible reason for the fragility of the result is that, unlike the return to acquiring some education, returns to college fell uniformly during the sample period-see Fig. 2. It may be hard to empirically distinguish between a provincial trend and a decreasing return to college during the period.

\subsubsection{Specification checks: unemployment-adjusted wages, unaffected cohorts and females}

The returns to education are not only observed in higher wages, but also in a lower probability of losing the job-see De La Fuente and Jimeno (2009). To account for the differential incidence of unemployment among skill groups, we adjust the measure of wages (3) as follows

$$
\bar{W}_{s, p, t}=\sum_{j=1}^{j=6} \pi_{s, j, p, 1995} \bar{w}_{s, j, p, t}\left[1-P\left(U_{S, j, p, t}\right)\right]
$$

That is, we weight the average wage of unskilled workers in collective agreements by the province-specific probability of being unemployed among workers with basic education level and ages between 26 and 35 when the cohort was 17 . The measure assumes that income is zero when a young adult that does not work-i.e., we ignore unemployment benefits. We adjust the returns of mid-skill (high-skill) workers by multiplying $\bar{W}_{\text {mid_skill }}$ (resp. $\bar{W}_{\text {college }}$ ) by 1 minus the probability of being unemployed by workers with vocational training or only with upper secondary school (resp. college). The probability of being unemployed is computed only among active workers and ignores non-participants. The results of the new measure are shown in Table 6, panel E. In that specification, we also control for the ratio of unemployment rate between the unskilled and the mid-skilled workers as well as for the ratio of unemployment between the mid-skilled and the high skilled. The results are similar to those in panel $\mathrm{D}$, and we do not comment them in detail.

\section{Unaffected male cohorts}

Given the description of the characteristics of the schooling system in Table 12, by age 22 schooling decisions are basically determined. If increases in low-skill wages 
affect the schooling decisions of young adults that are completing education, we may worry that the variation in low-skill wages is really capturing other factors. Hence, we turn to examine if the U-shaped change in low-skill wages between 1993 and 2001 affects the schooling attainment at age 25 of cohorts that are 22 years when the wage structure by skill level is measured. Panel F of Table 7 shows an increase of $10 \%$ in the wage of laborers relative to mid-skill workers leads to an increase of $4.4 \%$ in the chances of completing either vocational or at least high school - although the standard error is 2.4 percentage points. The comparable estimate in Table 6 Panel A suggests that an increase in the wage of laborers relative to mid-skill workers reduces the fraction of youths completing vocational or high school by $6.5 \%$ (standard error: $1.8 \%$ ). Hence, increases in low-skill wages diminish the chances of completing any form of secondary schooling among youths that are around the age to start working, but not those of older cohorts.

\section{Responses of females to the wage structure of males}

A second specification test examines if the educational attainment of females react to the wage structure of males. Absent peer effects or other types of social interactions, the wage structure observed by females at the age of 17 cannot be affected much by construction, as the share of unskilled females working in that industry is negligible. Hence, an effect of the wage structure of males on the educational attainment of females can point either at social interactions or a misspecification problem. The results in Panel G of Table 7 suggest basically no impact of the wage structure that males faced at the age of 17 on the educational attainment of females at age 25 .

\subsubsection{Responses by parental background}

Next, we examine what groups are most responsive to changes in the wage structure observed at 17 . We expect that less patient youths -or those with a higher marginal propensity for present consumption- are specially sensitive to increases in $\frac{\bar{W} \text { unskilled }}{\bar{W} \text { mid_skill }}$ . We do not have information about parental income and education, to decisively disentangle between parental education and parental income effects. Still, we can re-estimate the multinomial logit for subsamples of coresident youths with different parental background. When we compare the response of educational attainment in rows 1 and 3 of Table 8 we find much larger point estimates of $\frac{\bar{W} \text { unskilled }}{\bar{W} \text { mid_skill }}$ in the subsample of males whose mothers had completed at most compulsory education than in the subsample of mothers with at least a high school degree. As in Tables 6 and 7 , once we condition on province-specific trends, we fail to detect a statistically or economically relevant response of educational attainment of changes in $\frac{\bar{W} \text { mid_skill }}{\bar{W} \text { college }}$.

\subsubsection{The response of the schooling attainment of females}

The educational attainment of females also stagnated among Spanish nationals, but to a lesser extent than for males-see Fig. 1b. The wage growth in the sectors where unskilled females typically work (retail and restaurants+hotels) was also higher than 
Table 8 Schooling attainment at age 25 and return to skill at age 17-males, by parental background. Source: own computations using the Spanish Employment Survey (EPA, 2001-2009) merged with wages in the Registry of collective agreements (1993-2001)

\begin{tabular}{|c|c|c|c|}
\hline & \multicolumn{3}{|c|}{ Multinomial logit } \\
\hline & Prim. School & Voc. Tr. & Upper secon. \\
\hline \multicolumn{4}{|c|}{ Panel A: Coresidents, mother with basic schooling (covariates: provincial trends) } \\
\hline \multirow{2}{*}{$\begin{array}{l}\text { 1. Wage laborers/wage } \\
\text { mid-skill age } 17\end{array}$} & .066 & .020 & -.087 \\
\hline & $(.030)^{* *}$ & $(.044)$ & $(.058)$ \\
\hline \multirow{2}{*}{$\begin{array}{l}\text { 2. Wage mid-skill/wage } \\
\text { high-skill at age } 17\end{array}$} & .028 & -.016 & -.012 \\
\hline & $(.030)$ & $(.044)$ & $(.048)$ \\
\hline \multicolumn{4}{|c|}{ Panel B: Coresident, mother with high school (provincial trends) } \\
\hline \multirow{2}{*}{$\begin{array}{l}\text { 3. Wage laborers / Wage } \\
\text { mid-skill at age } 17\end{array}$} & .018 & .033 & -.051 \\
\hline & $(.007)^{* *}$ & $(.025)$ & $(.029)^{*}$ \\
\hline \multirow{2}{*}{$\begin{array}{l}\text { 4. Wage mid-skill/wage } \\
\text { high-skill at age } 17\end{array}$} & .011 & -.008 & -.002 \\
\hline & $(.006)$ & $(.0235)$ & $(.025)$ \\
\hline
\end{tabular}

Estimation method: Multinomial Logit. The coefficients shown are marginal effects of an increase in 10 percentage points in the ratio of bargained wages in each row on the probability of achieving the educational outcome shown in the relevant column. All specifications include province and year dummies, and the ratio of the unemployment rate of unskilled to skilled workers in the province

The responses are evaluated for a young adult interviewed in Madrid, born in 1974 and living with both parents

that in skill-intensive industries. Hence, it can be argued that females' incentive to acquire higher education also fell during the sample period.

Table 9 redoes the exercise for the sample of females but modifying the measure of wages (2) to take into account that $\pi_{s, j, p, 1995}$ are gender specific. According to Panel A of Table 9 cohorts that observed a $10 \%$ increase in the ratio of unskilled wages to mid-skill ones had a 2.4 pp lower probability of achieving primary schooling at most by age 25 . Note that the sign of the estimate reverses that of males, but it is not statistically different from zero.

Unlike in the case for males, there is some evidence of a response of schooling attainment to increases in the relative wage of high-skilled jobs. When we control for parental background, a $10 \%$ increase in the ratio of the wages in high-skill jobs relative to mid-skill ones decreases by 0.99 percentage points the share of females completing vocational training at the age of 25 (Panel B, row 4, column 2) and increases by $.96 \mathrm{pp}$ the fraction completing upper secondary or more (Panel B, row 4, column 3). Interestingly, the negative response of vocational training to increases in high-skilled wages is robust to the inclusion of province level trends.

The differential pattern of responses for females and males may reflect saliency. $30 \%$ of unskilled young male workers were employed in the construction sector in the early 2000s (see Fig. 3). Furthermore, the cumulative bargained nominal wage growth in the sector between 1997 and 2003 was $26.5 \%$, while the ("skilled") alternative of 
Table 9 The response of schooling attainment of females at age 25 to the return to skill of females at age 17 - measured using collective agreements

\begin{tabular}{|c|c|c|c|}
\hline & $\begin{array}{l}\text { Primary } \\
\text { education }\end{array}$ & $\begin{array}{l}\text { Vocational } \\
\text { training }\end{array}$ & $\begin{array}{l}\text { Upper secondary } \\
\text { or higher }\end{array}$ \\
\hline & (1) & (2) & (3) \\
\hline \multicolumn{4}{|c|}{ Panel A: Full sample (province and year dummies) } \\
\hline $\begin{array}{l}\text { 1. Wage laborers/wage mid-skill at age } \\
17\end{array}$ & -.0236 & .006 & .0174 \\
\hline $\begin{array}{l}\text { (service }+ \text { construction }+ \text { retail }+ \text { metal }+ \\
\text { rest })\end{array}$ & $(.0161)$ & $(.013)$ & $(.0226)$ \\
\hline $\begin{array}{l}\text { 2. Wage mid-skill/wage high-skill at age } \\
17\end{array}$ & .0042 & .005 & -.009 \\
\hline $\begin{array}{l}\text { (service }+ \text { construction }+ \text { retail }+ \text { metal }+ \\
\text { rest })\end{array}$ & $(.018)$ & $(.007)$ & $(.021)$ \\
\hline Number of observations: & 23,532 & & \\
\hline \multicolumn{4}{|c|}{ Panel B: Coresidents (covariates: former plus education of mother) } \\
\hline $\begin{array}{l}\text { 3. Wage laborers/wage mid-skill at age } \\
17\end{array}$ & -.003 & .0057 & -.0023 \\
\hline $\begin{array}{l}\text { (service }+ \text { construction }+ \text { retail }+ \text { metal }+ \\
\text { rest })\end{array}$ & $(.0043)$ & $(.0092)$ & $(.0115)$ \\
\hline $\begin{array}{l}\text { 4. Wage mid-skill/wage high-skill at age } \\
17\end{array}$ & .00036 & .0099 & -.0096 \\
\hline $\begin{array}{l}\text { (service }+ \text { construction }+ \text { retail }+ \text { metal }+ \\
\text { rest })\end{array}$ & $(.0045)$ & $(.0048)^{* *}$ & $(.0081)$ \\
\hline \multicolumn{4}{|c|}{ Panel C: Coresidents (covariates: former plus province trends) } \\
\hline $\begin{array}{l}\text { 5. Wage laborers/wage mid-skill at age } \\
17\end{array}$ & -.003 & .0057 & -.0023 \\
\hline $\begin{array}{l}\text { (service }+ \text { construction }+ \text { retail }+ \text { metal }+ \\
\text { rest })\end{array}$ & $(.0043)$ & $(.0092)$ & $(.0115)$ \\
\hline $\begin{array}{l}\text { 6. Wage mid-skill/wage high-skill at age } \\
17\end{array}$ & -.0005 & .0073 & -.0068 \\
\hline $\begin{array}{l}\text { (service }+ \text { construction }+ \text { retail }+ \text { metal }+ \\
\text { rest })\end{array}$ & $(.0045)$ & $(.0045)^{*}$ & $(.0057)$ \\
\hline Number of observations: & 17,647 & & \\
\hline
\end{tabular}

See notes to Table 6

services to businesses accumulated a nominal wage increase of $21 \%$. In that sense, the increase in male low-skill wages could be salient. Conversely, unskilled females work in services to firms, food and accommodation and retail, whose cumulative bargained nominal wage growth was lower: $21 \%, 25 \%$ and $22 \%$, respectively. In their case, it is likely that the fall in the returns to schooling was not as noticeable as that of males. Of course, other explanations are possible. ${ }^{20}$

$\overline{20}$ Abramitzky and Lavy (2014) document a higher response to incentives to complete upper secondary school among males than among females. In our case, the different evolution of wage growth for males and females does not permit such comparisons. 


\section{Discussion}

\subsection{Results using observed wages}

Our implicit assumption is that actual wages are equilibrium prices, influenced by unobserved supply and demand factors. For example, the wages of young unskilled workers and dropout decisions are determined simultaneously-a sudden increase in the fraction of youth that drops out is likely to affect the equilibrium wages of unskilled workers. We have shown that wages in collective agreements reflect mostly the outside opportunities of older workers. This subsection investigates the possible role of demand and supply factors by estimating the main model (2) but using observed wages derived from administrative data from Social Security records (rather than wage floors in collective contracts).

The response of the probability of completing primary school to the relative wages of unskilled workers is shown in Tables 10 and 11 . The results are qualitatively similar when we use actual wages or the wage structure in collective agreements. However, the composition of youths who continue studying (as inferred by a multinomial logit specification) varies depending on the measure of relative wages. When we use observed wages, the negative response of schooling attainment to an increase in unskilled wages comes at the expense of the vocational track. The results in Tables 10 and 11 are similar to those in López-Mayán (2010), who uses an structural model and measures of the wage structure based on observed ("equilibrium") wages to estimate that vocational training route fell most as a result of the increase in low-skill wages.

Now, note that the estimates using observed wages may capture changes in the composition of the labor force, while the evidence in Table 3 suggests that changes in the wage floors reflect primarily demand shifts. An interpretation of the fall in the fraction of individuals completing vocational training detected in Tables 10 and 11 is that the demand for those studies fell during the nineties. In that respect, Felgueroso et al. (2014) document an increase in dropouts from vocational training following a change in the national curriculum.

\subsection{Comparison to other estimates and assessing the magnitude}

Our preferred estimates suggest that an increase in the ratio of low- to mid-skill wage levels of $10 \%$ diminishes the probability that a young male achieves more than a basic school degree by around $6.5 \mathrm{pp}$. The finding is somewhat larger than that reported in Abramitzky and Lavy (2014), who estimate that an increase in the returns to college of $10 \%$ increase the chances of obtaining the equivalent to a high school diploma by $4 \%$. Furthermore, Abramitzky and Lavy also find larger effects among males with weaker backgrounds. In this paper, we have focused instead in increases in low- to mid-skill wages.

Our estimates can also be compared to those in Aparicio (2016), who estimates that a $10 \%$ increase in the returns to schooling decrease enrollment by about $1 \%$. Part of the discrepancy between our results and hers may come from differences in the measures of the returns to schooling. In particular, she uses a ratio of college 


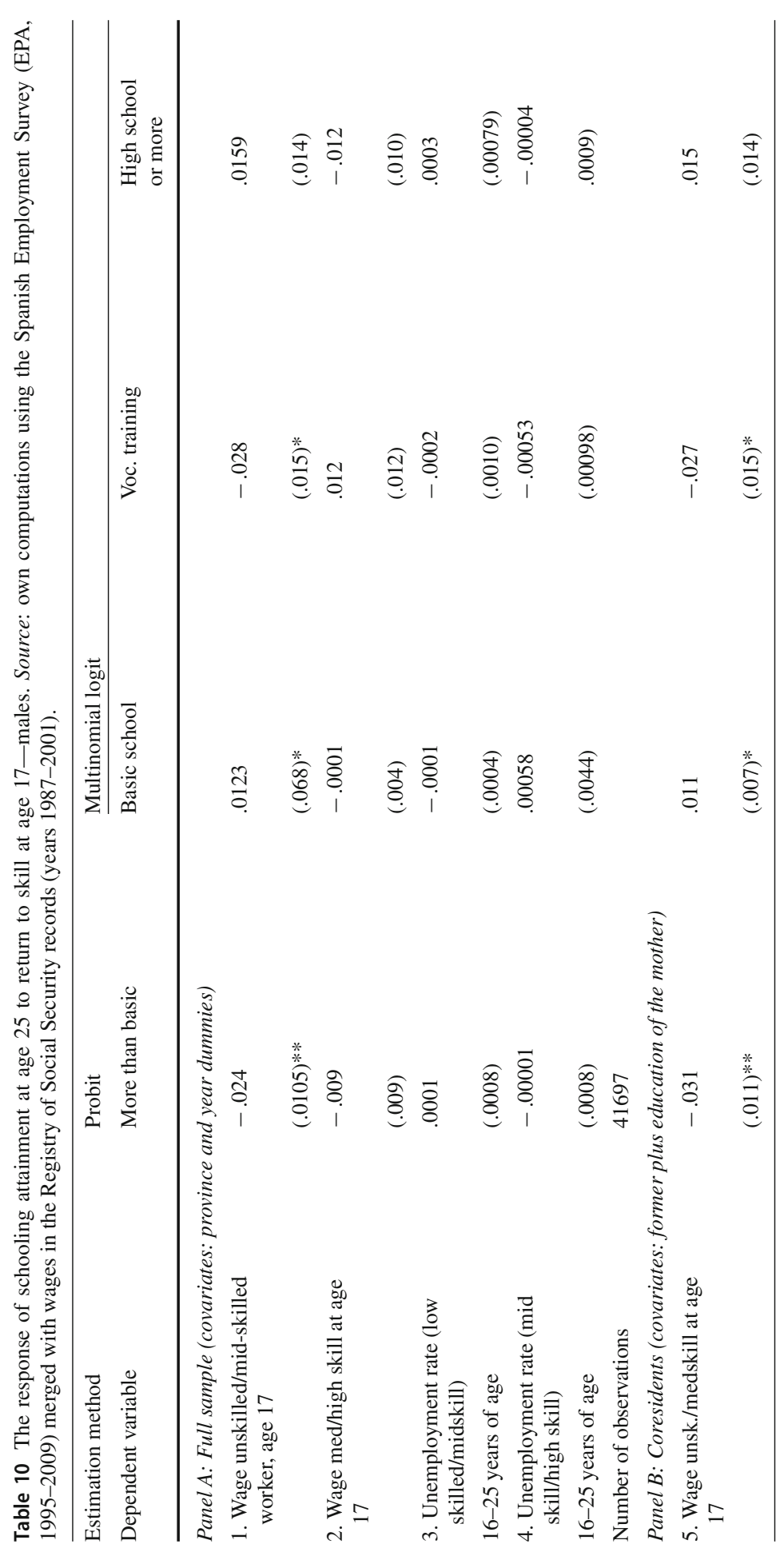




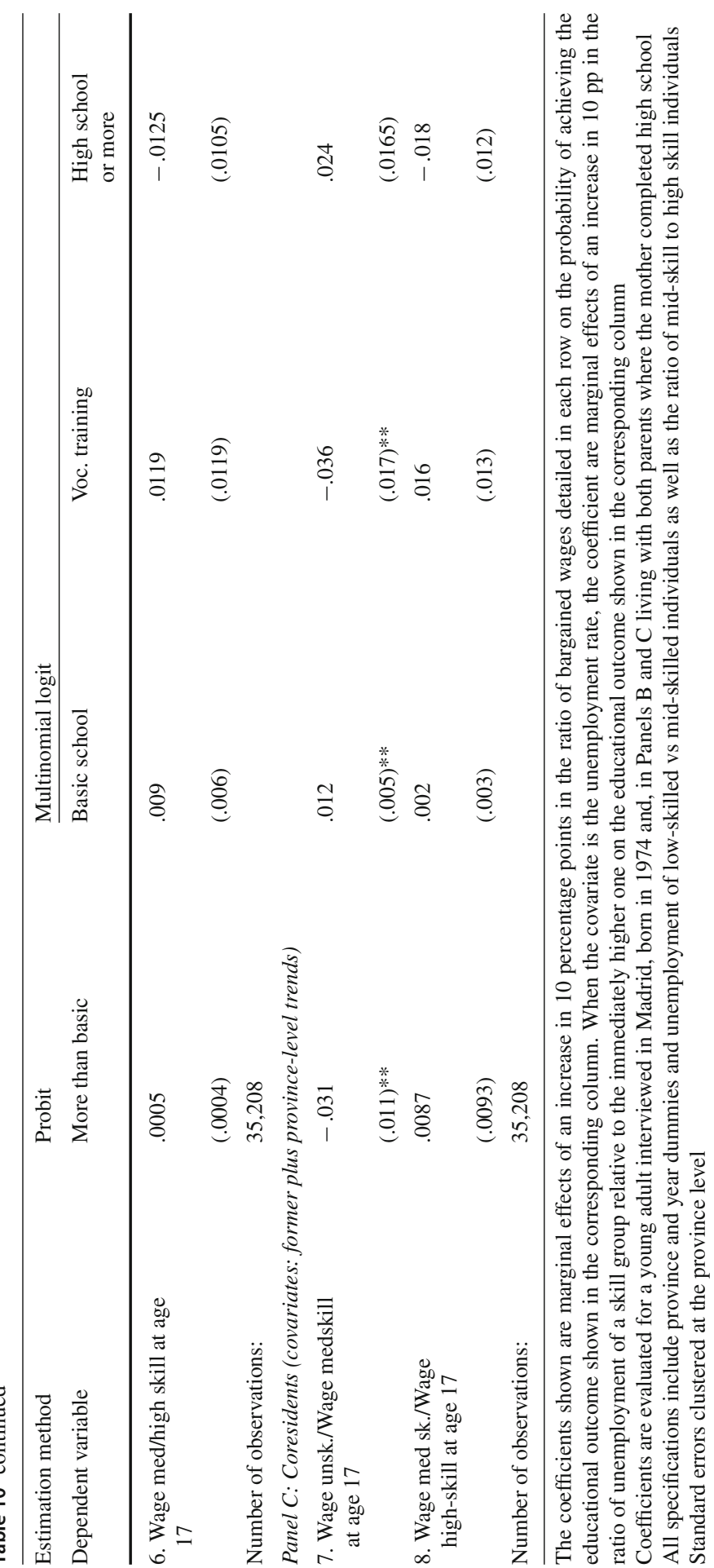


Table 11 The response of schooling attainment at age 25 to return to skill at age 22-males

\begin{tabular}{|c|c|c|c|c|}
\hline \multirow{2}{*}{$\begin{array}{l}\text { Estimation } \\
\text { method } \\
\text { Dependent } \\
\text { variable }\end{array}$} & \multirow{2}{*}{$\begin{array}{l}\text { Probit } \\
\text { More than basic }\end{array}$} & \multicolumn{3}{|c|}{ Multinomial logit } \\
\hline & & Basic school & Voc. training & HS+ \\
\hline \multicolumn{5}{|c|}{ Panel D: Full sample (covariates: province and year dummies) } \\
\hline \multirow{2}{*}{$\begin{array}{l}\text { 9. Wage } \\
\text { unsk./medskill }\end{array}$} & -.013 & .0203 & .000 & -.021 \\
\hline & $(.011)$ & $(.013)$ & $(.011)$ & $(.017)$ \\
\hline \multirow{2}{*}{$\begin{array}{l}\text { 10. Wage med } \\
\text { /high skill }\end{array}$} & .032 & -.044 & .013 & .030 \\
\hline & $(.014)^{* *}$ & $(.014)^{* *}$ & $(.026)$ & $(.023)$ \\
\hline $\begin{array}{l}11 . \\
\text { Unemployment } \\
\text { rate (low } \\
\text { skilled/midskill) }\end{array}$ & .0012 & -.0005 & .001 & -.0004 \\
\hline $16-25$ years of age & $(.0007)$ & $(.0008)$ & $(.0007)$ & $(.0002)$ \\
\hline $\begin{array}{l}12 . \\
\text { Unemployment } \\
\text { rate (mid } \\
\text { skill/high skill) }\end{array}$ & -.0005 & .0009 & -.0002 & -.0007 \\
\hline $16-25$ years of age & $(.0013)$ & $(.0013)$ & $(.0007)$ & $(.0012)$ \\
\hline $\begin{array}{l}\text { Number of } \\
\text { observations: }\end{array}$ & 42286 & & & \\
\hline
\end{tabular}

See notes to Table 10

over basic education, whereas we add an intermediate wage. With this more complex wage structure, we find that wages of low- to mid-skill correlates with educational enrollment but the ratio of mid- to high-skill wages does not (Table 5). To verify to what extent the difference in wage measures explains the differences between both studies, we reran the specification in Table 6, Panel B, row 3, but including the ratio of unskilled-to-college wages only. Indeed, once we collapse both measures $\frac{\bar{W} \text { unskilled }}{\bar{W} \text { mid_skill }}$ and $\frac{\bar{W} \text { mid_skill }}{\bar{W} \text { college }}$ into a single one $\left(\frac{\bar{W} \text { unskilled }}{\bar{W} \text { college }}\right)$, the 4.8 estimate in Table 6, Panel B, row 3 dropped to 2.8 .

Overall, our results of the schooling response to changes in the wage structure are in the ballpark of previous studies. However, we highlight a new finding: the supply of "abstract" skills is more sensitive to low-skill wages than that of vocational skills.

\subsection{Counterfactual evolution of schooling attainment}

The working paper version of this study conducts the following counterfactual: What would have been the schooling attainment of the 1984 cohort had it faced at age 17 the wage structure that the 1978 cohort observed? (see Lacuesta et al. 2012). We first predict for each individual his educational attainment at age 25 based on the wage 
structure observed at 17 . The restrictions implicit in the multinomial logit specification guarantee that the predicted shares of educational attainment for each cohort coincide with the actual ones. We then predict the educational attainment when, holding constant the rest of the covariates, we replace the wage structure observed by the 1984 cohort in the same province. The results suggest that the observed changes in the wage structure have contributed substantially to the distribution of educational attainment. For example, within the cohort of males born in 1984, 36\% completed at most basic schooling. The fraction was $33.2 \%$ among the 1976 cohort. According to our estimates, had the 1984 cohort observed the returns of the 1978 one, the corresponding share of youths with basic schooling would have been $34.2 \%$. That is, changes in the wage structure would explain 1.8 percentage points of the 2.8 observed increase. The model does worse when fitting the evolution of the share of youths with vocational training and the academic high school track.

\section{Conclusion}

Between 1986 and 2009, Spain experienced a drop and a subsequent increase in the wage of unskilled young workers relative to mid-skill ones. That ratio diminished during the 1992 crisis but increased steadily during the subsequent expansion, that involved a large increase of the unskilled labor-intensive construction sector. At the same time, the schooling attainment of Spanish cohorts born before 1976 increased at a regular pace, but stagnated after that cohort. We use the wage structure by skill level in collective agreements to obtain variation in wages that unskilled workers effectively get and that, we argue, reflect primarily demand factors. Unlike previous work, we examine the response of final schooling attainment to changes in the return to skill. Hence, our estimates can inform about how perceived returns may affect the final set of skills acquired in the formal education system (academic skills in upper vocational branch and professional skills acquired in the vocational branch).

Our preferred estimates suggest that changes in the wage structure have effects on the composition of skills that males acquire in the formal education system. In particular, the increase in the unskilled to mid-skill wages ratio observed between the years 1993 and 2001 led to a 5 percentage points increase in the fraction of youth who completed primary education (or less), mainly at the expense of the proportion of youth completing upper high school. The effect is concentrated among the sons of low-educated mothers and is robust to adjustments for differential incidence of unemployment across education groups. Reassuringly, the relative increase in lowskill wages in a male-dominated industry did not affect the schooling decisions of females. On the contrary, we estimate weak schooling responses to perceived wage increases in high-skill jobs. As for females, we document a weak response of the probability of investing in academic skills in response to relative increase in high-skill wages, but no response whatsoever to increases in wages in low-skilled jobs. Overall, our findings suggest that the investment in academic skills (abstract tasks) is more elastic to unskilled wages that investments in skills directly related to professional activities (service or routine tasks). 
Our results imply that expansions, even if temporary, of sectors that are intensive in low-skill employment may have long-run implications on the type of skills that are supplied to the labor market. In the particular case of Spain, one can expect that the construction bust will drive cohorts turning now working age to invest more in schooling. Secondly, our estimates have implications on the average skill level in the economy: an important group of workers has replaced "academic" skills acquired in formal school by on-the-job skills acquired in a very particular industry. Finally, intergenerational mobility may be affected by the expansion in construction, as the sons of low-education mothers responded most to the relative increase in low-skill wages. A quantification of those effects is left for further research.

Funding This study was not funded by any particular fund.

\section{Compliance with ethical standards}

Conflict of interest The authors declare that they have no conflict of interest regarding this research.

Human participants or animals performed This article does not contain any studies with human participants or animals performed by any of the authors.

Open Access This article is licensed under a Creative Commons Attribution 4.0 International License, which permits use, sharing, adaptation, distribution and reproduction in any medium or format, as long as you give appropriate credit to the original author(s) and the source, provide a link to the Creative Commons licence, and indicate if changes were made. The images or other third party material in this article are included in the article's Creative Commons licence, unless indicated otherwise in a credit line to the material. If material is not included in the article's Creative Commons licence and your intended use is not permitted by statutory regulation or exceeds the permitted use, you will need to obtain permission directly from the copyright holder. To view a copy of this licence, visit http://creativecommons.org/licenses/by/4.0/.

\section{Appendix I: Correspondence between schooling levels, both systems}

This appendix describes our assumptions to make a correspondence between systems. Table 12 shows the educational system before and after 1990.

Basic schooling: Equivalent to 8th grade of primary schooling (or less) under the old system and second cycle (or less) under the new one.

Upper secondary schooling: Equivalent to finishing pre-University (and high school) under the old system, and the second cycle of upper secondary schooling under the new one.

Vocational training: Completing any of the grades under both systems. Ideally, we would like to distinguish between grades within each systems and, even better, across systems. Unfortunately, the coding in the Spanish Employment Survey does not allow a clear correspondence between the old and the new system. We lumped together all vocational training together, and note that students finishing the degree under the new system may be better qualified than those under the old system if the first grade of vocational training was prevalent under the old system.

College: Any form of academic college under any of both systems. 


\section{Appendix II: Constructing wage information}

We construct information about wages using the Muestra Continua de Vidas Laborales: Wave 2007. That source contains a $4 \%$ random subsample of individuals who were affiliated to the Social Security system in 2007 (either as employees or as unemployed), with information about the monthly earnings of all employers since the moment when the person joined the Social Security system. The register contains high quality information on wages, but it lacks reliable information about the education level of young workers. ${ }^{21}$ We construct proxies of wages by skill level using the fact that workers are grouped into 11 categories for Social Security purposes. ${ }^{22,23}$

We construct a measure of the expected wage profile over a lifetime if the worker obtains tertiary education (first two contribution groups) intermediate education (groups 3-9) or no education at all (group 10 or laborers) assuming a zero interest rate. The exact measure of wages is the following

$$
W_{s, p, t}=\sum_{g=1}^{g=3} .33 * \operatorname{Med}\left[W(s)_{g, p, t}\right]
$$

where $g$ is an index for age group (we use three groups: 16-25, 26-35 and 36-45), $p$ is an index of the 50 provinces, $t$ refers at the year of measurement, and $s$ is the skill level. $W(s=10)$ is the wage of workers classified as laborers, that we use to define unskilled workers. We construct similar measures for mid-skill workers (same age groups, but using $W(s=3 \ldots 9)$ skill groups 3-9) and for high-skill workers $W(s=1 \ldots 2)$ - see Table 3 .

Finally, most of the results use not actual wages, but wage floors set in collective contracts. Table 13 shows that about half of unskilled workers between 18 and 35 in the construction sector earned between 1993 and 2000 monthly wages at most 5\% higher than their corresponding wage floor.

\footnotetext{
21 There is a measure of schooling in the dataset that was obtained by linking the Social Security Registers with information with the Population Registry. The latter is a city-level register of individuals who live in each address and contains some self-reported demographic information. Unfortunately, the information in the Registry is only updated when individuals change their address and may not be accurate for young individuals who have not changed address in the latter years.

22 Admittedly, there are cases of individuals with a college degree whose employer pays wages according to contribution groups other than the first two, leading us to overestimate the returns to college. Nevertheless, a study of the evolution of the wage structure in Spain in Felgueroso et al. (2016) documents that returns to skill using contribution groups or education level give a very similar picture.

23 There are two possible concerns with our measure of earnings. The first is that monthly earnings are capped at the maximum wage that the Social Security uses to compute contributions to old age and health pensions. We address that issue by focusing on medians that, for workers below 45 years of age are insensitive to the problem of censoring. The second problem is the presence of selective attrition from the labor force, the sampling method does not guarantee that the wage that a worker in 2006 perceived ten years before is representative of the past distribution of earnings. Hence, we use only males' earnings, as that subgroup is less likely to drop out from the labor force.
} 


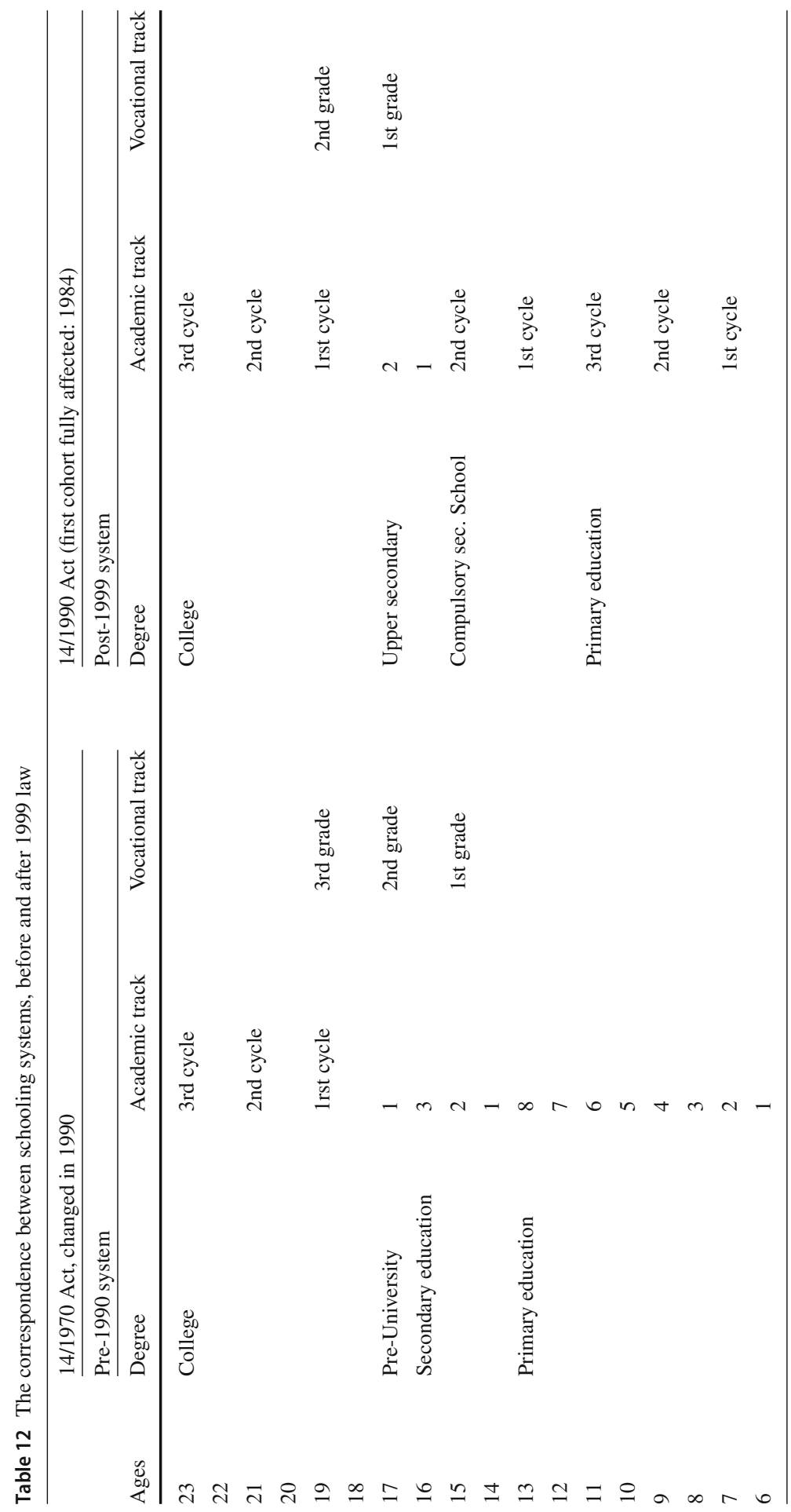


Table 13 The bite of collective contracts in the construction sector: laborers 18-35. Source: Muestra Continua de Vidas Laborales (1993-2000) matched to the Registro de Convenios Colectivos

\begin{tabular}{|c|c|c|c|c|c|c|c|c|}
\hline $\begin{array}{l}\text { Fraction of } \\
\text { workers whose } \\
\text { earnings are: }\end{array}$ & 1993 & 1994 & 1995 & 1996 & 1997 & 1998 & 1999 & 2000 \\
\hline $\begin{array}{l}\text { 1. Below } .975 \\
\text { times wage floor }\end{array}$ & 14.68 & 11.90 & 10.79 & 12.28 & 11.29 & 10.1 & 8.96 & 8.92 \\
\hline $\begin{array}{l}\text { 2. Between } .975 \\
\text { and } 1.05 \text { times } \\
\text { wage floor }\end{array}$ & 26.26 & 28.93 & 30.96 & 31.72 & 28.85 & 26.87 & 23.00 & 27.86 \\
\hline $\begin{array}{l}\text { 3. Between } 1.05 \\
\text { and } 1.1 \text { times } \\
\text { wage floor }\end{array}$ & 23.01 & 23.10 & 18.95 & 19.41 & 23.32 & 25.99 & 28.62 & 22.04 \\
\hline $\begin{array}{l}\text { 4. Between } 1.1 \\
\text { and } 1.2 \text { times } \\
\text { wage floor }\end{array}$ & 20.43 & 20.68 & 23.85 & 25.03 & 22.89 & 22.33 & 23.51 & 22.79 \\
\hline $\begin{array}{l}\text { 5. Above } 1.2 \text { times } \\
\text { wage floor }\end{array}$ & 15.61 & 15.39 & 15.45 & 11.60 & 13.7 & 14.67 & 15.92 & 18.38 \\
\hline Sample size: & 5232 & 5939 & 5999 & 5441 & 6492 & 9289 & 10,927 & 9209 \\
\hline
\end{tabular}

Sample of males between 18 and 35 years of age working in construction as full time laborers (group 10 in social security classification by skill)

The sample includes workers with at least 6 months of tenure at the firm

\section{References}

Abramitzky R, Lavy V (2014) How responsive is investment in schooling to changes in redistributive policies and in returns. Econometrica 82(4):1241-1272

Anghel B, De la Rica S, Lacuesta A (2014) The impact of the great recession on employment polarization in Spain. SERIES 5:143-171

Aparicio A (2016) Returns to education and educational outcomes: the case of the Spanish housing boom. J Human Capital 10(2):235-265

Atkin D (2016) Endogenous skill acquisition and export manufacturing in Mexico. Am Econ Rev 106(8):2046-85

Autor D, Levy F, Murnane R (2003) The skill content of recent technological change: an empirical investigation. Q J Econ 118(4):1279-1333

Bartik T (1991) Who benefits from state and local economic development policies?. W.E. Upjohn Institute for Employment Research, Kalamazoo

Becker G (1962) Investment in human capital: a theoretical analysis. J Polit Econ 70(5):9-49

Beffy M, Fougére D, Maurel A (2009) Choosing the field of study in post-secondary education: Do expected earnings matter?. IZA Discussion Paper N. 4127

Black D, McKinnish T, Sanders SG (2005) Tight labor markets and the demand for education: evidence from the coal boom and bust. Ind Labor Relat Rev 59(1):3-16

Bonhomme S, Hospido L (2017) The cycle of earnings inequality: evidence from Spanish social security data. Econ J 127:1244-1278

Buchinsky M, Leslie P (2010) Educational attainment and changes in the U.S. wage structure: dynamic implications on young individual's choices. J Labor Econ 28(3):541-594

Cameron S, Taber C (2004) Estimation of educational borrowing constraints using returns to schooling. J Polit Econ 112(1):132-182

Card D, de La Rica S (2006) Firm level contracting and the structure of wages in Spain. Ind Labor Relat Rev 59(4):573-592

Card D, Lemieux T (2001) Can falling supply explain the rising return to college for young men? A cohort level analysis. Q J Econ 116(2):705-746 
Carneiro P, Lee S (2011) Trends in quality-adjusted skill premia in the United States, 1960-2000. Ame Econ Rev 101(6):2309-2349

Charles K, Hurst E, Notowidigdo M (2018) Manufacturing busts, housing booms, and declining employment: a structural explanation. Am Econ Rev 108(10):2947-94

Clark D (2011) Do recessions keep students in school? The impact of youth unemployment on enrolment in post-compulsory education in England. Economica 78(311):523-545

De La Fuente A, Jimeno J (2009) The private and fiscal returns to education. J Eur Econ Assoc 7:1319-1360

Delavande A, Zafar B (2019) University choice: the role of expected earnings, non-pecuniary outcomes and financial constraints. J Polit Econ 127(5):2343-2393

Dellas H, Sakellaris P (2003) On the cyclicality of schooling: theory and evidence. Oxford Econ Pap 55:148-172

Felgueroso F, Gutierrez-Domenech M, Jiménez S (2014) Drop-out trends and educational reforms: the role of the LOGSE in Spain. IZA J Labor Policy 3:9

Felgueroso F, Hidalgo M, Jiménez S (2016) The fall of wage skill premium. Manch School 84:390-435

Goos M, Manning A, Salomons A (2009) Job polarization in Europe. Am Econ Rev Pap Proc 99(2):58-63

Gould E, Mustard D, Weinberg B (2002) Crime rates and local labor market opportunities in the United States: 1979-1997. Rev Econ Stat 84(1):45-61

Guner N, Kaya E, Snchez-Marcos V (2014) Gender gaps in Spain: policies and outcomes over the last three decades. SERIEs 5:61103

Izquierdo M, Moral E, Urtasun A (2003) Collective bargaining in Spain: an individual data analysis. Banco de España Working Paper N. 0302

Juhn C, Murphy K, Pierce B (1993) Wage inequality and the rise in returns to skill. J Polit Econ 101(3):410442

Lacuesta A, Izquierdo M (2012) The contribution of changes in employment composition and relative returns to the evolution of wage inequality: the case of Spain. J Popul Econ 25:511-543

Lacuesta A, Puente S, Villanueva E (2012) The schooling response to a sustained increase in low-skill wages: evidence from Spain (1989-2009). Banco de España Working Paper No. 1208

López-Mayán C (2010) Demand for post-compulsory education: the choice between academic and vocational tracks. Mimeograph, Universitat Autonoma de Barcelona

Lovenheim M (2011) The effect of liquid housing wealth on college enrollment. J Labor Econ 29(1):741771

Manski C (1993) Adolescent econometricians: How do youths infer the returns to schooling? In: Clotfelter C, Rothschild M (eds) Studies of supply and demand in higher education. University of Chicago Press, Chicago, pp 43-60

Manski CF (2004) Measuring expectations. Econometrica 72(5):1329-1376

Moretti E (2013) Real wage inequality. Am Econ J Appl Econ 5(1):65-103

Neumark D Wascher (1995) Minimum wage effects on employment and school enrolment. J Bus Econ Stat 1:199-206

Petrongolo B, San Segundo M (2002) Staying-on at school at 16: the impact of labor market conditions in Spain. Econ Educ Rev 21:353-365

Pijoan-Mas J, Sanchez-Marcos V (2010) Spain is different: falling trends of inequality. Rev Econ Dyn 13(1): $154-178$

Sanders SG, McKinnish T, Black D (2005) Tight labor markets and the demand for education: evidence from the coal boom and bust. Ind Labor Relat Rev 59(1):3-16

Publisher's Note Springer Nature remains neutral with regard to jurisdictional claims in published maps and institutional affiliations. 